\title{
La Amazonia en el quehacer del Seminario de Historia Rural Andina (1977-2015)
}

\author{
María Belén Soria Casaverde \\ msoriac_ac@unmsm.edu.pe \\ Universidad Nacional Mayor de San Marcos \\ Facultad de Ciencias Sociales \\ Instituto Seminario de Historia Rural Andina
}

\section{SUMILLA:}

Este artículo tiene por objeto hacer un balance de la producción historiográfica y artística sobre la región de la Amazonia peruana emprendida por el Seminario de Historia Rural Andina (SHRA) en estos cincuenta años. Al respecto, se tomará en consideración los criterios teóricos y metodológicos que dirigieron el rescate del patrimonio histórico documental (manuscritos e impresos), oral (testimonios y relatos) y de arte nativo (pintura y tallados), que permitieron construir la "otra historia" desde la perspectiva de la identidad, transculturalidad y alteridad, recogiendo la mirada de los pueblos amazónicos y cómo estos materializan el mundo espiritual a través del arte. Basados en el curso seguido por la producción historiográfica del SHRA en el período 1977-2015, se ha dividido el trabajo en dos períodos: el primero, centrado en la historia de la colonización mestiza, y el segundo, abocado al rescate de la tradición oral. Ambos períodos no son excluyentes sino complementarios y manifiestan la vocación integradora del trabajo historiográfico del SHRA.

Palabras-clave: Perú; Historiografía Amazónica; Historia Oral; Arte Amazónico; Interculturalidad; Seminario de Historia Rural Andina.

\section{The Amazonian cultural area: The scientific contribution of the Seminario de Historia Rural Andina (1977-2015)}

\begin{abstract}
:
This article presents a review of the historiographical and artistic studies on the Peruvian Amazonian area since the decade of 1970. In order to rescue and study documentary data (manuscripts and printings), oral history information (personal testimonies, oral history), and native art (paintings and carvings) specific theoretical and methodological criteria have been applied so that the "other's history" could be understood better. Analytical approaches concerning Identity, transcultural aspects, and otherness, attempt to recover Amazonian people's vision and its expression through art. The discussion is presented in two periods: first, mestizo colonization history and second, rescue of oral traditions. However, they sometimes overlap.

Keywords: Peru; Amazonian Historiography; Oral History; Amazonian Art; Interculturality; Seminar of Andean Rural History.
\end{abstract}




\section{Introducción}

$\mathrm{L}$ a Amazonia peruana ocupa casi dos terceras partes de nuestro país y está poblada por numerosas ciudades mestizas y comunidades indígenas. Posee una gran megadiversidad biológica, lingüística y cultural. Estas cualidades la convierten en un espacio geoeconómico y ecológico singular. Sin embargo, durante siglos la historiografía y cátedra universitaria han descuidado el estudio de la Amazonia. Por ese motivo, no fue sino hasta el año 2009 cuando se creó un curso electivo sobre temas amazónicos en el plan curricular de la escuela de Historia de la Facultad de Ciencias Sociales de la Universidad Nacional Mayor de San Marcos (UNMSM). Anteriormente, la Unidad de Posgrado de la misma facultad, bajo la dirección del Dr. Manuel Burga, había creado la Maestría de Estudios Amazónicos. Este programa académico fue desactivado después de casi una década de funcionamiento, a causa del cambio de dirección y la escasez de recursos.

Tradicionalmente, ese distanciamiento histórico de la Amazonia tiene su origen en la dispersión de la documentación escrita por misioneros y autoridades de la región, almacenadas en iglesias, prefecturas y municipios u otras entidades públicas o privadas, que dificultaban el acceso a dicha información. A ello se suman los prejuicios culturales que los gobiernos tuvieron y tienen del "otro" (pueblos indígenas) por su condición de culturas ágrafas, la perecibilidad de sus productos culturales, vistos como "rarezas" o "curiosidades", y el carácter profundamente espiritual de sus tradiciones orales, cargadas de simbolismo y misticismo. A continuación, nos preguntamos ¿cómo el escenario político nacional propició la difusión de los estudios amazónicos del país? y ¿de qué manera el SHRA promovió la realización de investigaciones sobre historiografía amazónica?

\section{Primera Etapa: Rescate de la historia colonizadora y mestiza}

La década de 1970 fue crucial para el desarrollo de los estudios amazónicos. En 1974, el Gobierno de Juan Velasco Alvarado promulgó la Ley de Comunidades Nativas y Promoción Agraria de las Regiones de la Selva Alta y Selva Baja (Ley N. ${ }^{\circ}$ 20653), que reconoció el derecho de los pueblos indígenas sobre sus tierras y les otorgó propiedad legal sobre Estas. Por estos años, surgieron los primeros centros de investigación especializados en la Amazonia. En 1972, los religiosos agustinos fundaron en Iquitos el Centro de Estudios Teológicos de la Amazonía (CETA), mientras los jesuitas establecieron, dos años después en Lima, el Centro Amazónico de Antropología y Aplicación Práctica (CAAAP). El Servicio Evangélico Peruano de Acción Social (SEPAS), creado en 1976, trabajó con artesanos, cooperativas de mujeres, iglesias y postas médicas andinas y amazónicas. Asimismo, en 1978, surgió el Centro de Investigación y Promoción Amazónica (CIPA). Por su parte, el Seminario de Historia Rural Andina (SHRA), fundado en 1966 por Pablo Macera estudió el aspecto económico de las haciendas y agricultura peruanas e inició sus investigaciones amazónicas a partir de 1977.

Durante esta primera etapa, el SHRA dio preferencia a la publicación de fuentes y la reedición de estudios e informes antiguos, poco conocidos y/o extraviados, como La Memoria sobre la amazonia peruana, 1901 del presbítero David Muñoz. Dicho texto, publicado en 1980, contiene interesantes descripciones de caminos y pueblos nativos de la cuenca del Marañón. También podemos mencionar la edición del Diccionario topográphico do departamento de Loreto na República do Perú, 1874 de Joao Wilkens De Mattos (cónsul general del Brasil en Loreto), traducido del portugués al español por Rosario Jiménez y con prólogo de Pablo Macera, texto de 
suma importancia porque traza el estado demográfico, administrativo y económico de Loreto y sus relaciones con Brasil. En 1992, el CIPA y el SHRA publicaron tres volúmenes bajo el título de Geografía Amazónica. Siglo XIX, los cuales compilaron informes remitidos por los prefectos y subprefectos de Huánuco, Loreto y Amazonas a la Dirección Nacional de Estadística, a cargo entonces de Agustín de la Rosa Toro. Esos informes nos describen un espacio amazónico dominado por la "pobre dureza de la vida cotidiana" tanto que resultaba difícil para los colonizadores imponer reglas mínimas de la lejana civilización mirada como modelo, pues "los caminos casi no existían”. ${ }^{1}$ Poco después (1993), el CIPA financió la catalogación de la Sección Tierras de Montaña e Inmigración del Archivo General de la Nación. La catalogación estuvo a cargo de Luz Peralta y un grupo de estudiantes de historia de la UNMSM y la Universidad Nacional Federico Villareal (UNFV). ${ }^{2}$ Posteriormente Pablo Macera dio importancia a un grupo de expedientes del Archivo Arzobispal de Lima con el fin de que los investigadores del SHRA analizaran y publicaran la información contenida en estos. Recibí entonces un conjunto de documentos sobre la actuación de párrocos y obispos de Maynas y Chachapoyas desde la Independencia hasta mediados del siglo XIX. Dicho material me permitió iniciar mis investigaciones históricas referidas a la Amazonia con la publicación del libro Administración eclesiástica amazónica. Siglo XIX (1997).

En el campo de la producción historiográfica, el SHRA dio apertura en 1977 a la publicación de la tesis del historiador José Flores Marín, La Explotación del caucho en el Perú. En esa misma línea, en 1985, el estudio histórico Viajes y exploraciones en la Amazonía peruana 1550-1975 de Carlos Dávila fue publicado gracias a una coedición realizada por el SHRA y el Seminario de Estudios Antropológicos de la Selva (SEAS). Carlos Dávila, fundador del SEAS, era conocido entonces como el "charapólogo", debido a su acuciosidad por investigar la Amazonia desde todos los ángulos.

El SHRA también impulsó estudios arqueológicos a partir del

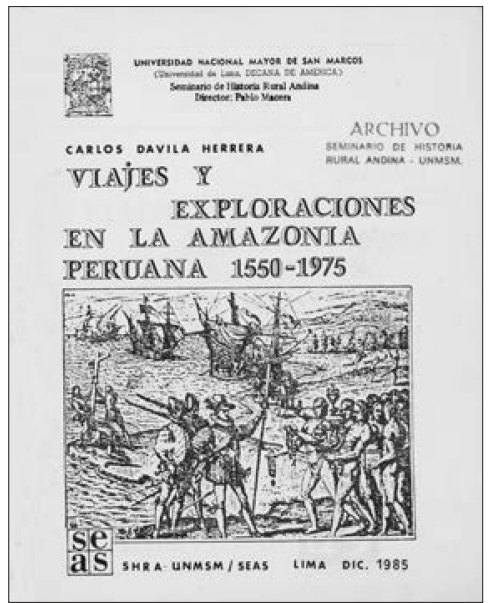

Carátula de libro Viajes y Exploraciones en la Amazonía Peruana 1550-1975; Lima-1985. redescubrimiento del centro ceremonial de Pacopampa (1966), ${ }^{3}$ que motivó la organización de sucesivos viajes de exploración, cuyos resultados fueron publicados por Jaime Miasta en dos libros. En el primero, titulado El Alto Amazonas. Arqueología de Jaén y San Ignacio. Perú, a partir de sus excavaciones y levantamientos topográficos, registró arte rupestre que reveló una presencia humana muy antigua en estos valles. En el segundo, El Alto Amazonas. Arqueología de Jaén y San Ignacio. Perú. Anexo, presentó material gráfico (fotos, láminas, dibujos) sobre los artefactos líticos y cerámica hallados en esta exploración.

Por su parte, Daniel Morales en su libro Hacia las rutas de Vilcabamba: último reducto de resistencia incaica (1979) también realizó trabajos de arqueología amazónica en la zona selvática

$1 \quad$ Macera 1992: IV-V.

2 Esta labor fue efectuada por la historiadora Luz Peralta y los estudiantes Omar Rojas, Sonia Challco, Gloria Sánchez, María Andazabal, Luis Alberto Meneses, Gonzalo Luis Gonzáles y Jesús Varillas. Ellos revisaron y catalogaron 20,200 expedientes agrupados en 245 legajos (Peralta 1993: s/n). El proyecto contempló la publicación del catálogo en tres volúmenes, pero solo circuló el primero que contenía el 30\% de la información clasificada. Desde entonces se halla pendiente la digitación de las fichas correspondientes al resto de material catalogado, a fin de que estos puedan ponerse al servicio del investigador.

3 Gracias al patrocinio de Emilio Choy, el SHRA adquirió para la Universidad Nacional Mayor de San Marcos los terrenos donde se ubica el Centro Ceremonial de Pacopampa (Cajamarca). 
del Cusco, a fin de trazar el plano y datación de la ciudad donde habitaron los últimos incas hacia fines del siglo XVI. Más tarde, Morales publicó Los alfareros de Huánuco (1981), donde establece cierta continuidad entre la tradición estilística de la cerámica confeccionada por cultura selvática de Kotosh en el Intermedio y la que elaboraban varios pueblos huanuqueños en la década de 1980.

Paralelamente a estos esfuerzos del SHRA, otras instituciones dedicadas a los estudios amazónicos comenzaron a publicar varios manuscritos, como las crónicas misioneras, relatos de viajeros y los informes de autoridades políticas y de las juntas de vías fluviales, todos los cuales están referidos a espacios y períodos históricos determinados. Muchas de estas fuentes han sido compiladas desde 1984 por el CETA en su colección Monumenta Amazónica. De igual forma, el CAAAP en el decenio de 1980 editó su revista Amazonia Peruana, pionera en la investigación amazónica.

A esa producción bibliográfica podemos agregar los trabajos de Avencio Villarejo, Stefano Varese y Jesús San Román, y últimamente los de Fernando Santos Granero, Pilar García Jordán, Nuria Sala i Vila, Frederica Barclay, Jaime Regan y Waldemar Espinoza, estos dos últimos profesores de nuestra Casa de Estudios. Todos ellos, entre otros, ofrecen importantes datos y reflexiones sobre la historia amazónica peruana. En la última década del siglo XX, se observó mayor dinamismo en la realización de investigaciones sobre la realidad amazónica. Sin embargo, algunos historiadores, como Jesús San Román, señalaban que la historia de la selva peruana aún estaba por escribirse. ${ }^{4}$

El SHRA siempre careció de recursos propios y los pocos que podía conseguir dependían de las gestiones personales efectuadas por Pablo Macera. A pesar de estas limitaciones, el SHRA investigó, publicó y repartió gratuitamente sus textos a los estudiantes y profesores de la comunidad sanmarquina. Entre 1977 y 1997 el SHRA produjo catorce libros sobre historia amazónica desde la perspectiva de la sociedad colonizadora y mestiza. Sin duda, las comunidades nativas también eran actoras y productoras de historia, pero los historiadores tradicionales estaban dominados por el errado concepto de que los pueblos carentes de escritura alfabética eran ahistóricos. Ellos asocian la historia a la escritura y no perciben que los pueblos ágrafos poseen memoria histórica. Como veremos más adelante, los kené de los shipibo-konibo y las iconografías de los pueblos arawak, jibaro, piro o bora, constituyen formas de transmitir y preservar ideas en el tiempo. Por otra parte, aun cuando no existiese un "recuerdo histórico" de la manera como se entiende desde la perspectiva occidental, esto no invalida la presencia de otras formas de rememorar un "proceso histórico" y eso también puede considerarse historia. De esa constatación nació el interés del SHRA por impulsar el rescate de las tradiciones orales, conocimientos intergeneracionales y las experiencias cotidianas de las comunidades amazónicas.

\section{Segunda Etapa: Rescate de la historia indígena amazónica (1997-2015)}

De 1997 al año 2015, las investigaciones amazónicas del SHRA pusieron especial interés en abordar la interculturalidad y narrativa bilingüe (34\%), pero también se ocuparon del arte nativo (31\%), cuestiones históricas (13\%) y antropológicas (19\%) y la publicación de documentos inéditos (2\%). A partir de 1997, Pablo Macera emprendió varios proyectos en coordinación con la UNESCO y el Instituto Nacional de Cultura (INC) con el propósito de estudiar el proceso creador de la memoria colectiva y la historia oral, destacando la necesidad de establecer puntos de encuentro entre la cultura escrita y las representaciones simbólicas de las culturas nativas. La coordinación general de

4 San Román 1994: 15. 
este trabajo me fue encargada. En el marco de dicho proyecto, varios migrantes nativos visitaron el SHRA y nos revelaron aquellos seres mágicos que moran en sus cosmovisiones mediante relatos, pinturas sobre llanchama (corteza de árbol), modelado en cerámica, bordados y tallados de madera. Por esa razón, Pablo Macera, entusiasmado por la fuerza expresiva de las llanchamas de Churay, viajó a Loreto para conocer el entorno en que estaba desarrollándose ese movimiento cultural, tal como lo recuerda Luis Arista, entonces director del Instituto Nacional de Cultura Peruana:

Ya Macera promocionaba, por aquel entonces [1997], las pinturas hechas con tintes naturales sobre llanchamas, como las realizadas por el pintor bora Víctor Churay. Es por eso que visitamos la comunidad bora: viajamos en canoa por el Amazonas, y caminando a través del tupido y húmedo bosque, aplicando en ciertos trechos el paso de loro, para no caernos. ${ }^{5}$

Entre 1998 y 1999, varios artistas nativos recibieron apoyo del SHRA para que lograran abrirse espacios de reconocimiento en Lima. Por entonces, la crítica academicista y los circuitos de difusión (galerías) denominaban "artesanía” (manualidad) a todas las obras artísticas que no encajaban con los estándares estéticos occidentales. Ese criterio recogía la diferencia establecida, desde los tiempos de la Ilustración, entre las nociones de “cultura académica” y “cultura popular”, que reservó para la primera el monopolio de la reproducción de la belleza, mientras juzgó a la segunda como el resultado de la torpeza intelectual y la vulgaridad de las costumbres propias de la chusma. ${ }^{6}$ Ello explica porque el establishment cultural peruano había sido siempre hostil y excluyente con las artes indígenas. $\mathrm{Al}$ respecto, Pablo Macera, señaló que:

El arte popular y las artesanías del siglo XX (en el Perú y otros países) provienen de un Cuarto Mundo al interior del Tercer Mundo. El Cuarto Mundo es el segmento más carencial dentro de su sociedad respectiva, en relación subordinada a otros sectores de la población y con una posición marginal o menor dentro del proceso de modernización que desde el 'Primer Mundo' ha sido impulsado en el Tercer Mundo. ${ }^{7}$

Esos artistas autodidactas, precisó Pablo Macera, forjaron en los talleres del SHRA las condiciones para iniciar "un nuevo estilo pictórico en el Perú”8 ¿Cómo nació dicho estilo? ¿Quiénes fueron sus iniciales representantes? ¿Cuáles fueron sus retos? Sin duda, esta pintura nativa, signada por la afirmación étnica en un contexto urbano, surgió como resultado de un diálogo intercultural propiciado por el SHRA, a partir de la propuesta pionera del artista bora Víctor Churay. A continuación, daremos respuesta a estas preguntas presentando la producción plástica y narrativa de esos artistas amazónicos.

\section{Víctor Churay: abriendo camino}

Víctor Churay (Pucaurquillo, Loreto, 1972-Lima, 2002) fue un joven pintor bora, que inició su carrera artística participando, junto a otros artistas nativos, en una expo-sición colectiva desarrollada en Leticia (Colombia) en 1994. Obtuvo después sucesivamente uno de los primeros puestos en

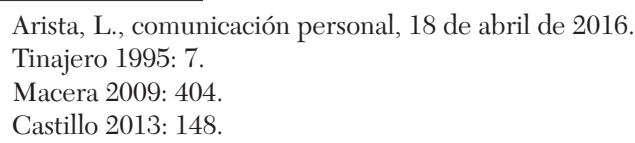


el "IX Concurso Nacional de Dibujo y Pintura Campesina" (1995) y en el "I Concurso de Arte nativo sobre corteza de llanchama” (1996). Realizó su primera exposición individual en la Galería FORMAS de Miraflores. Una segunda muestra individual en la misma galería recibió el apoyo del SHRA. Por esos años, Víctor y el cineasta Fernando Valdivia emprendieron el proyecto de filmar un documental sobre la búsqueda del tinte azul en la selva. En 1997, llegó al SHRA y fue invitado por Pablo Macera para escribir e ilustrar relatos de la tradición oral bora dentro de los proyectos "Quilca-Llanchama" (INC, 1997) y

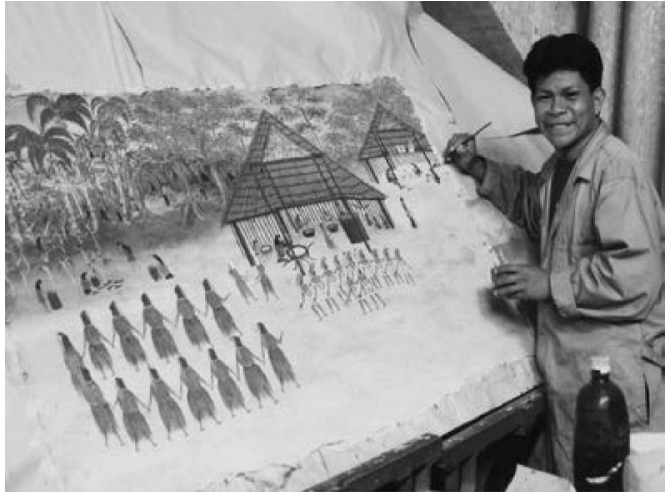

Víctor Churay en los talleres del Seminario de Historia Rural Andina, Lima-1998. Foto: Archivo MBSC. "Pintura y Palabra" (UNESCO, 1998).

El pincel de Víctor poseía la espiritualidad mágica y sensibilidad artística de las culturas indígenas. Hasta entonces pintaba cuadros sobre las costumbres, vida cotidiana y mitos de la cosmovisión bora, abriendo a nuestros ojos los enigmas de las cochas, bosques y animales encantados. Sin embargo, su verdadero potencial creativo despertó en los talleres del SHRA cuando renovó su temática incorporando cuadros antropológicos e históricos, que mostraban vívidamente los recuerdos de la explotación sufrida por su pueblo en la época del caucho. ${ }^{9}$ De esa manera, el SHRA fue el espacio fecundo donde surgió la Escuela de la Llanchama. ${ }^{10}$ En setiembre de 1998, las nuevas pinturas de Víctor fueron exhibidas en la muestra Llanchamas Bora. Víctor Churay Roque, organizada por el SHRA en el Museo del Banco Central de Reserva del Perú. Para aquilatar cuál era la trascendencia de la obra de Víctor Churay, el diario La República publicó un reportaje donde Pablo Macera respondió esta pregunta en los siguientes términos:

Víctor Churay no es un pintor naif; es solo un pintor. A veces, popular y naif son categorías que componemos para otra pintura, la que no entendemos. Para los boras las pinturas sobre corteza de árbol (ojé y caucho macho) son instrumentos sociales que aseguran su identidad y su memoria. Podría parecer para algunos una pintura pobre en pigmentos, materiales, propuestas especiales. Cuanto lo que tiene es disciplina, contención, no usar más de lo necesario. Esta pintura sin golosinas empieza a ser descubierta por nosotros los habitantes de la ciudad y se incorpora como una selva al imaginario colectivo peruano. ${ }^{11}$

Los cuadros de la citada exposición reflejaron el proceso de introspección cultural emprendido por Víctor para encontrar sus raíces étnicas. Por eso, pintó el mapa de su región, el plano de la comunidad de Pucaurquillo, el mapa bora del cielo, los símbolos de los clanes bora y el misterioso manguaré, además de otras escenas extraídas de los mitos y relatos de su pueblo. De esta época, el cuadro más celebrado de Víctor fue la Cosmovisión bora, pintada sobre una llanchama de gran tamaño, donde describe la organización cósmica y espacial de su cultura concebida a través de la interrelación de tres espacios mágicos (mundos): Tierra del agua (hábitat de peces y reptiles), tierra donde vivimos (lugar del hombre y la naturaleza) y tierra de las estrellas (morada del "creador”) y los antiguos espíritus (abuelos). Las fuerzas del bien (ímí) y mal (ímítyú) aparecían en este

9 Yllia 2009: 101-102.

10 Macera 2004: s/n

11 Escribano, 1998 
cuadro rigiendo todo un universo de seres reales y sobrenaturales repartidos en diversos espacios relacionados con el pueblo bora mediante una serie de visiones y mitos. ${ }^{12}$ Este cuadro, pintado por Víctor en el taller del SHRA, se exhibe en forma permanente en la Sala de Arte Popular del BCRP.

Gracias a Víctor, entablamos comunicación con su padre, el curaca Víctor Churay Flores, su tía, Julia Mibeco, descendiente del líder bora Mibeco, y Eduardo Soria. Ellos vinieron al SHRA y durante varios días nos brindaron información sobre las tradiciones festivas de los bora, profusas en el uso de pinturas y máscaras fabricadas desde la época de sus abuelos. Surgió entonces la idea de seleccionar y trasladar a Lima una colección de esas máscaras. Para cumplir dicha tarea viajé a Iquitos en setiembre de 1998. Con parte de ese material, adquirido por Pablo Macera, el SHRA decidió organizar la exposición titulada Báhjaá Meéme/Fiesta del Pijuayo, que fue realizada en el Museo Nacional de la Cultura Peruana en noviembre de 1998 y cuya curaduría estuvo a mi cargo. Víctor fue además entrevistado por el programa Lector de Estrellas de la Televisión Nacional del Perú (TNP), donde detalló el simbolismo ritual de esta celebración.

Años después, el libro Fiestas tradicionales de los bora (2001) reunió testimonios y descripciones de las canciones, danzas y coreografías de las celebraciones del pueblo bora. Una década después, antropólogos de la Universidad Nacional de Colombia y la Corporación Tapioca dentro de su programa de inventario de los conocimientos tradicionales de los pueblos indígenas amazónicos organizaron la exposición Saberes de pupuña, el chontaduro en la Amazonia (2014) para mostrar los rituales celebrados con motivo de la cosecha de la pupuña, nombre con el que los colombianos conocen al pijuayo (Bactris gasipaes). Esta palmera, una de las primeras domesticadas por el hombre amazónico, ofrece abundantes frutos ricos en aceite y nutrientes básicos. En la mitología bora, el pijuayo fue obra de Mekaani (creador bora) y sus cuatro variedades (cuatro gigantes palmeras) sostienen el mundo. La palmera ubicada al oriente tiene abundantes espinas (microcarpa) y es conocida como el pijuayo de los peces. Un antiguo mito bora cuenta que el pez tarijpa sembró el primer pijuayo y propagó su cultivo. En otro relato, esta acción fue realizada por el hombre pucunero ayudado por las aves trompeteros (déénehe) y el pez tarijpa, pues antes solo el Dóóránie Bóóa ("Padre infinito de los peces") poseía pijuayo dentro del agua para alimento de los peces. ${ }^{13} \mathrm{La}$ exposición y el libro del SHRA sobre la Fiesta del Pijuayo quisieron contribuir a su preservación, pues se hallaba en riesgo de desaparecer. Sin embargo, corresponde al Estado apoyar su práctica en las comunidades boras de Pucaurquillo y Brillo Nuevo y declararla Patrimonio Cultural de la Nación. Ciertamente, la Fiesta del Pijuayo reafirma los vínculos del hombre bora con el cosmos y constituye una de las principales expresiones musicales y coreográficas de los pueblos nativos de la Amazonia.

Víctor trabajó en los talleres del SHRA hasta inicios del año 2000, fecha en que se retiró para seguir estudios en la escuela de Historia de la UNMSM, pues quería ampliar sus conocimientos sobre el pasado nacional y el de su pueblo. Estaba consciente de que necesitaba prepararse para convertirse en líder de su pueblo y promover la defensa de su cultura desde la alcaldía o prefectura de su provincia. Por eso, decía: “... nadie mejor que un indígena para mostrar las cosas valiosas de su pueblo" (Valdivia 2003). En abril del año 2002, Víctor falleció en Lima, pero su esforzado y valioso trabajo de promoción cultural había abierto espacios en el circuito artístico limeño para la participación de otros pintores amazónicos autodidactas, como su hermano Jairo Churay, Roldán Pinedo, Elena Valera, Robert Rengifo, Lastenia Canayo, Enrique, David y Wilberto Casanto. Todos ellos, siguiendo el camino trazado por Víctor Churay, forjaron sus propuestas artísticas en los

12 Soria 1998: 17

13 Churay y Soria 2001: 82 
talleres del SHRA y expusieron sus obras en la Sala de Exposiciones del Colegio Real, para luego hacerlo en galerías de otras instituciones nacionales y extranjeras.

\section{Robert Rengifo: Chonomeni (el que pinta bonito)}

Hacia fines de 1997, el artista shipibo Robert Rengifo (Iparia, Ucayali, 1967) llegó al SHRA en compañía del narrador Herminio Vásquez. Ambos, por encargo de Pablo Macera, prepararon una serie de relatos ilustrados recopilados de la tradición oral shipibo-konibo. Robert había trabajado anteriormente como muralista de varios restaurantes de Pucallpa, y durante diez años (19861996), por invitación del biólogo Peter Birkenmeier y la antropóloga Kaethe Mentzen, ilustró las cartillas Nuestro Monte Tropical, auspiciada por la AIDESEP y el Instituto Tecnológico "Suiza”, y varios libros de la Comisión de Emergencia Asháninka (1996-1997). En el SHRA, Robert comenzó pintando con temperas sobre cartulinas, pero después asoció magistralmente el óleo, las temperas y resinas con los tintes naturales extraídos del

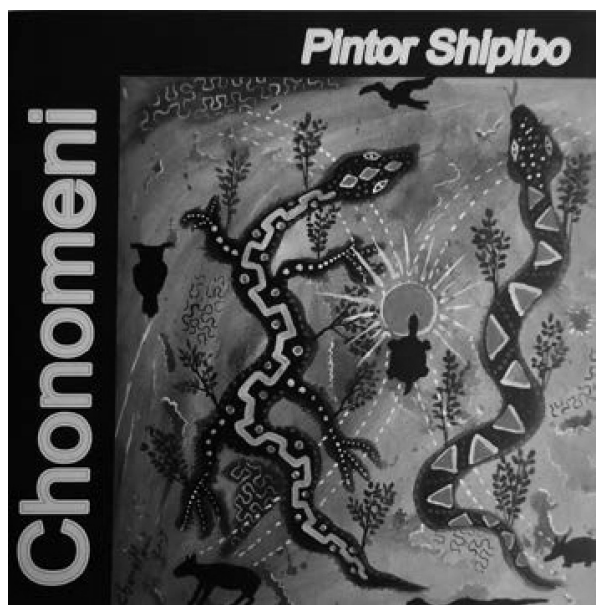

Tríptico de la exposición Telas Pintadas Shipibas. Roldán Pinedo y Elena Valera, Lima-1999. achiote (rojo), huito (negro), huitillo (morado), pijuayo (verde) guisador (anaranjado) y tierras de colores (blanco, gris, crema y amarillo). Igualmen-te, los lienzos reemplazaron a las cartulinas. Este nuevo formato le dio mayor espacio y libertad para pintar los escenarios y personajes mágicos de la cosmovisión shipiba. Culminado su trabajo en el SHRA, Robert regresó a Pucallpa donde acudió a sesiones de ingesta del ayahuasca, pues deseaba experimentar visiones que tendieran un puente mágico entre la vida cotidiana y el mundo espiritual. Entre los años 2005 y 2008, participó en la ilustración de cartillas de la Word Wildlife Fund (WWF) Perú y Servicios en Comunicación Intercultural Servindi. En setiembre del 2009, el SHRA realizó la muestra Chonomeni. Pintor shipibo en la Sala de Exposiciones Colegio Real, en setiembre de 2009, con el propósito de hacer conocidas la nueva galería de seres mágicos pintados por Robert en los últimos años.

\section{Roldán Pinedo y Elena Valera: las telas pintadas shipibas}

A mediados de 1998, Roldán Pinedo (Yarinacocha, Ucayali, 1971) y Elena Valera (Pucallpa, Ucayali, 1968) fueron invitados a trabajar en los talleres interculturales y bilingües del SHRA. Ambos son shipibos muy tradicionales en su estilo artístico, pues usaban como lienzos unas telas de tocuyo teñidas con caoba y pintaban con los materiales y gama cromática existentes en la naturaleza. La primacía del color marrón en sus trabajos se explica porque esa tonalidad identifica a su pueblo y está presente tanto en la cerámica como la mayor parte de sus vestidos (cushmas y shitontes). Ellos trajeron al SHRA una interesante propuesta de arte figurativo shipibo-konibo basada en la representación de la fauna amazónica. Roldán y Elena preferían pintar animales porque estos, según dijeron, poseen alma y vida

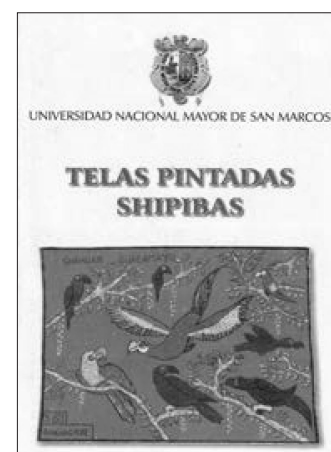

Roldán Pinedo y Elena Valera

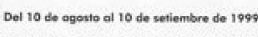

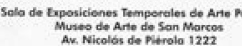

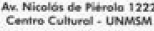

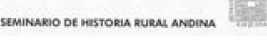

Catálogo de la Exposición Chonomeni. Pintor Shipibo, Lima-2009. 
autónomas tal como los hombres (joni). Según la cosmovisión shipiba, antiguamente los animales tenían apariencia humana y su nombre portaba la idea del joni en que iban a transformarse. Por esa razón, los nombres de muchos joni aluden a diversos animales. Por ejemplo, el nombre shipibo de Roldán es Shoyan Sheca (como el ratón) y el de Elena es Bahuan Jisbe (loro hablador). Ellos usan con orgullo esos nombres para difundir la autoría de sus pinturas colocándolos en los extremos de las telas pintadas debajo de un conjunto de kenés encerrados en un recuadro. Los kenés no solo constituyen una forma de lenguaje simbólico shipibo, sino que además fortalecen la identidad de este pueblo frente a las demás comunidades amazónicas ${ }^{14}$

En agosto de 1999, el SHRA organizó la exposición Telas pintadas shipibas. Roldán Pinedo y Elena Valera en la Sala de Exposiciones Temporales de Arte Popular del Museo de Arte de San Marcos. Al año siguiente, la Unidad de Posgrado de la Facultad de Ciencias Sociales de la UNMSM, jefaturada por el doctor Manuel Burga, auspició otra muestra en la Biblioteca Central de la misma universidad, bajo el título de Lo mágico y cotidiano en el arte shipibo. Roldán Pinedo y Elena Valera. El creciente interés de investigadores y público en general por conocer la obra de estos artistas motivó la edición del catálogo Arte Shipibo. Roldán Pinedo y Elena Valera (pintores), publicado el año 2001 por el SHRA. En los años siguientes, Roldán y Elena recorrieron caminos separados, aunque ocasionalmente han coincidido en exposiciones colectivas, como las muestras Amazonía al descubierto. Dueños, costumbres y visiones (Museo de Arte del Centro Cultural de San Marcos, octubre-diciembre 2005) y Amazónica. Corrientes, vertientes y emergencias (Centro Cultural Ricardo Palma, junio-julio 2011). Actualmente, ambos desarrollan una técnica mixta que conjuga los tintes naturales y el óleo. Este proceso evolutivo de la pintura nativa en el medio urbano capitalino pone de manifiesto cómo los artistas indígenas encuentran formas de utilizar los recursos técnicos occidentales para defender su identidad.

\section{La familia asháninka Casanto: David, Enrique y Wilberto}

Durante esta época se inició también el trabajo con las tradiciones orales asháninkas. Hacia fines de 1998, David Casanto, joven asháninka del Perené llegó al SHRA. Recién egresado de la escuela secundaria había venido a Lima, junto con sus padres, para intentar seguir estudios superiores en la capital. David tenía el don de dar vida con su pincel a los animales que conocía y lo habían rodeado en su niñez. Sin embargo, una grave enfermedad que se le manifestó cuando retornó a su comunidad impidió que pudiese desarrollar su potencial artístico en el SHRA. La partida de David, a pesar de las gestiones hechas por Pablo Macera para que recibiera atención médica en Lima, permitió establecer contacto con su tío Enrique Casanto (Puerto Bermúdez, Pasco, 1956). Hasta entonces, él había trabajado como promotor de salud y ejercido cargos dirigenciales en organizaciones del pueblo asháninka. A partir de conversaciones informales realizadas en el SHRA, Casanto compartió una gran cantidad de cuentos y relatos históricos por lo que fue invitado a participar en los proyectos interculturales que estaban en marcha. De esa

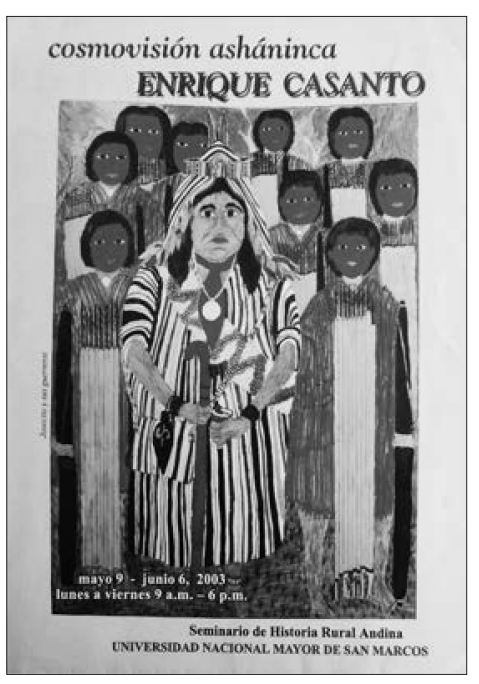

Díptico de la Exposición Cosmovisión Asháninka. Enrique Casanto, Lima-2003

14 Soria 2001:3 
manera, a principios de 1999, Casanto emprendió varias investigaciones sobre la tradición oral y la memoria histórica de los asháninka del Perené convirtiéndose en uno de los más activos representantes de la cultura amazónica en Lima.

Sus primeros textos y dibujos, pintados con plumones sobre cartulinas, nos revelaron una serie de mitos y relatos sobre los espíritus asháninkas del bosque. Después utilizó acuarelas y témperas para producir una galería de guerreros legendarios, personajes históricos y figuras mitológicas vinculados con el origen de los clanes asháninkas y la dispersión histórico-geográfica de las actuales comunidades. Estos seres antropomorfos tenían atributos mágicos y simbolizaban las fuerzas de la naturaleza. Por ejemplo, el guerrero Shenoronto poseía la velocidad del abejorro y vencía a sus rivales con rápidas y mortales estocadas como las que asesta dicho insecto. A su vez, el guerrero Oonkama obtenía su fuerza de la creciente del río, que utilizaba como estrategia de guerra para hundir las balsas y canoas de sus enemigos. ${ }^{15}$ Casanto continuó escribiendo y dibujando en el SHRA por espacio de quince años hasta su alejamiento a fines del 2014. Durante ese tiempo, publicó una cartilla alfabética y un cancionero asháninkas y varios libros sobre fauna, plantas medicinales y otras empleadas en la caza y pesca.

Casanto ha forjado además una escuela artística familiar, pues sus hijos también pintan y narran relatos asháninkas. En esa nueva generación de pintores destaca Wilberto Enrique Casanto Ríos (Kivinaki, Junín, 1978). Entre los años 1999 y 2003, provisto de plumones y cartulinas pintó diversas aves y mamíferos de la cuenca del Perené. En esas obras notamos cierto "realismo naturalista" en la representación de los animales que forman parte del mundo cotidiano del pueblo asháninka. En tiempos antiguos -dice Wilberto- los animales fueron personas, pero perdieron esa apariencia humana cuando adoptaron hábitos trasgresores de las normas de convivencia comunitaria. Posteriormente, las pinturas de Wilberto, plenas de "realismo mágico", desbordan misticismo y nos muestran hombres y animales dotados de poderes sobrenaturales y en medio de la fantástica naturaleza amazónica. Todos estos personajes tienen figuras estilizadas, con cuellos, piernas, brazos o patas alargadas. Varias de estas obras fueron seleccionadas y exhibidas en la muestra "De la selva sus amigos. Wilberto Casanto" (mayo-junio 2005), organizada por el SHRA en la Sala de Exposiciones del Colegio Real.

\section{El Proyecto Madres/Niñas y Lastenia Canayo}

En el curso de este trabajo de rescate de la tradición oral amazónica, Pablo Macera elaboró el Proyecto Madres/niñas, auspiciado por la UNESCO y respaldado por la UNMSM, cuyo propósito consistía en recopilar los cuentos y relatos cortos compartidos diariamente por las madres nativas con sus hijas. Durante el año 2000, las madres Anita Angulo Rodríguez, Lastenia Canayo García, Zoila Franchini Silvano, Diana Rodríguez Pacayo (shipibas) y Edith Casanto Ríos (asháninka) se reunieron en el SHRA para escribir y pintar los relatos atesorados por la memoria colectiva de sus pueblos. En sus textos percibimos la influencia ejercida por las costumbres y creencias introducidas en la Amazonia por los migrantes andinos y la prédica de las iglesias católica y evangélica.

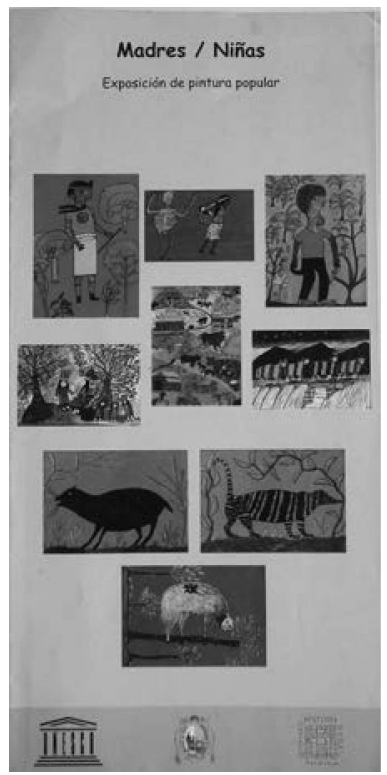

Tríptico de la Exposición Madres/Niñas, Lima 2000.

15 Macera y Soria 2003: 2. 
Asimismo, en las leyendas y narraciones de las madres shipibas destaca la presencia del Sol y la Luna, deidades reguladoras del espacio, tiempo y las actividades productivas. El lugar que ocupa esta pareja cósmica revela un activo proceso de comunicación intercultural entre las antiguas poblaciones andinas y amazónicas por la vía del Ucayali-Urubamba. Ese fue el caso de los piro chontaquiros, que de manera pacífica (trueque) o violenta (correrías) -precisa Alejandro Camino- establecieron contacto con los quechuas, shipibos y machiguengas. ${ }^{16}$ Ciertamente, los cuentos de las madres shipibas comprueban esta dinámica interrelación entre selváticos y andinos, que además está documentada por la información arqueológica y etnohistórica. Dichos textos también nos hablan de la comunicación mágica entre hombre y naturaleza producida a través de los "demonios" que habitan el bosque y transmiten sus poderes a las plantas utilizadas por los shipibos.

En mi condición de coordinadora de este proyecto tuve especial interés por las obras de Lastenia Canayo García (Roroboya, Ucayali, 1962), cuyo nombre shipibo es Pecon Quena (la que llama a los colores). De manera sorprendente, Lastenia recordó más de quinientos relatos sobre los espíritus de apariencia antropomorfa encargados de proteger animales, plantas y hasta las rocas del mundo shipibo-konibo. Estos Ibo (dueños) o Yoshin (diablos) regulan el uso de las plantas medicinales, el consumo de los mitayos y el acercamiento entre los hombres y las fuerzas desconocidas de la naturaleza. Por ejemplo, el Dueño del Ishpingo, provoca accidentes a quienes cortan y negocian en cantidad la madera de este árbol, pero consiente que la gente pobre la use para construir sus casas o fabricar herramientas. Este castigo de la sobreexplotación de los recursos ha ordenado la cosmovisión shipibo-konibo sobre la base del equilibrio ecológico. Parte de los citados relatos fueron incluidos por Pablo Macera en la edición bilingüe español-shipibo de los Cuentos Pintados del Perú, realizada el año 2002 por la Fundación Inca Kola con el fin de apoyar el trabajo educativo intercultural de los maestros y niños de la Amazonia. El Comité de Damas del Congreso de la República del Perú financió una segunda edición el año 2009, bajo el título Pirokan Moatian Jawekibo Ini Yoia Sika. Xoxo bana ibobo /Cuentos Pintados del Perú. Dueños de las plantas. Años antes, en junio del año 2004, el SHRA presentó la exposición Los dueños del mundo Shipibo/Conibo en la Sala de Exposiciones del Colegio Real-UNMSM. En simultáneo, el Fondo Editorial de la UNMSM publicó el libro Los Dueños del mundo shipibo. De ese modo, los Ibo se han convertido en objeto de interés antropológico y elemento novedoso para el trabajo de los artistas shipibos. Por eso, Lastenia los dibuja en cartulina, borda en tela y manda a tallar en madera para venderlos en las ferias artesanales.

\section{Domingo Casancho: arte nomatsiguenga}

En agosto del 2007, el profesor bilingüe nomatsiguenga, Domingo Casancho (San Ramón de Pangoa, Junín, 1960), exhibió una selección de sus pinturas en la muestra titulada Como un avispero. Cosmovisión nomatsiguenga, realizada por el SHRA en la Sala de Exposiciones del Colegio Real. El pincel de Casancho, dotado de fuerte expresividad, se impregna de la policromía del paisaje selvático para ofre-

16 Camino 1977: 127-128.

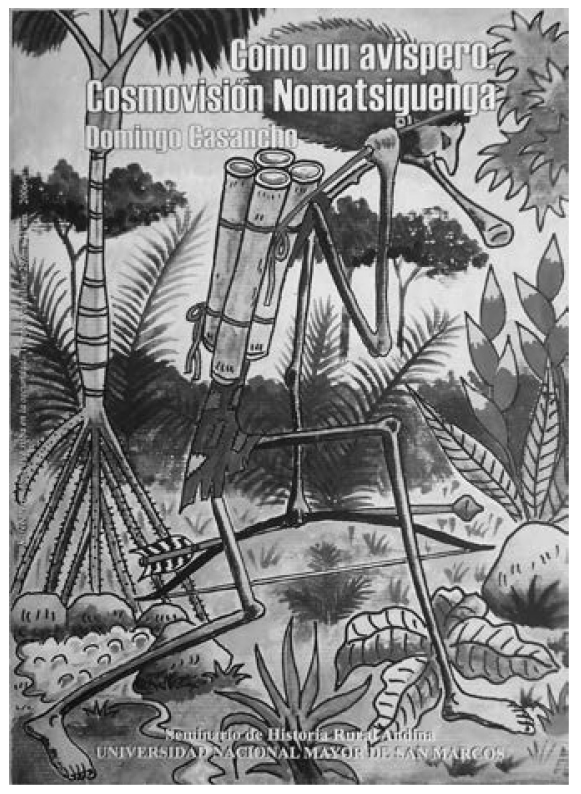

Díptico de la Exposición Yrapakatu. Pablo Taricuarima, Lima-2010. 
cernos una galería de misteriosos seres lejanos de los sentidos, pero cercanos a nuestros espíritus. Con suma destreza en el manejo de tonalidades y formas, sus composiciones reflejan la permanente interacción entre lo sagrado y maligno que se manifiesta en las actividades cotidianas del pueblo nomatsiguenga. De acuerdo con los relatos de Casancho, el cuerpo es la cushma del alma y esta tiene una prolongada existencia después de la muerte. Por ese motivo, los nomatsiguenga sepultan a sus difuntos en los cerros para que las aves sagradas, como el colibrí, recojan sus almas, las cuiden y alimenten hasta cuando puedan ingresar a los otros niveles del espacio rumbo al Jonokaguite (firmamento). En dicho lugar son sometidas a pruebas de convivencia y arrojadas al Tsiron Tsiro (tierra del fuego) cuanto tienen mal comportamiento. Comprometido con la difusión de la tradición oral nomatsiguenga, Casancho nos dice:

Todas las historias de mi pueblo jamás se pintaron y menos se escribieron, porque nadie sabía escribir, pero las manteníamos siempre vivas mediante la tradición oral, desde tiempos inmemoriales hasta nuestros días. Hoy me toca a mí, pintar y escribir para que todos sepan que somos una cultura viva. $^{17}$

\section{Pablo Taricuarima, pintor kukama egresado de la Escuela de Bellas Artes}

Pablo Taricuarima (Santo Tomás, Loreto, 1988) es un pintor kukama egresado de la Escuela de Bellas Artes de Lima.c En setiembre de 2010, la exposición "Yrapakatun, Pablo Taricuarima" organizada por el SHRA en la Sala de Exposiciones del Colegio Real, permitió apreciar su estilo artístico forjado a partir de los patrones estéticos aprendidos en la Escuela de Bellas Artes. En ese contexto, podemos preguntarnos ¿đde qué manera el arte académico puede vincularse con la pintura indígena contemporánea? Sobre este aspecto, en el Conversatorio "Las artes plásticas: narrativas y memorias" (Casa de la Literatura, 20 de junio de 2016), Pablo Taricuarima precisó que en la Escuela de Bellas Artes aprendió las técnicas artísticas (valor tonal, perspectiva, ritmo), pero estas nunca lo incentivaron a pintar la cosmovisión kukama, pues en sus aulas predomina el interés por estudiar las escuelas clásicas del arte occidental. En consecuencia, el proceso de retorno a sus raíces indígenas fue resultado de una

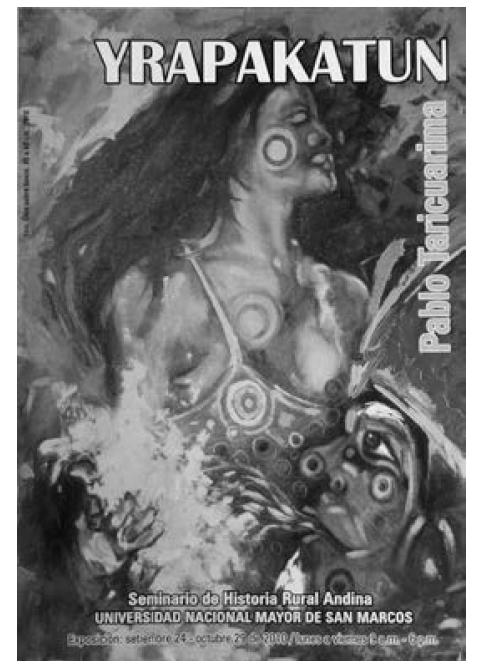
Díptico de la Exposición Yrapakatu. Pablo Taricuarima, Lima-2010. elección personal motivada por el deseo de rescatar y difundir las tradiciones de su pueblo. Sin embargo, la defensa de la identidad étnica no debe imponer ninguna forma de aislamiento, sino que debe orientarse hacia la interculturalidad. Esto puede notarse en el festival Yrapakatun, organizado por Pablo Taricuarima y un colectivo de jóvenes artistas desde el año 2010 en la comunidad de Santo Tomás, donde las danzas y tradición oral de diversas comunidades kukamas son expuestas y compartidas con visitantes de otras zonas del Perú y el extranjero.

En sus cuadros, Pablo Taricuarima combina pinceladas cortas, sueltas y creativas y fusiona colores de diferente luminosidad (primarios y complementarios) para revelarnos los espacios físicos y espirituales de la cosmovisión kukama. Los personajes destacados en la galería mágica de Pablo son los mashakaras, danzantes enmascarados participantes de la festividad donde los kukamas

17 Macera y Soria 2007: 4. 
celebran un pacto con los espíritus del monte, y el Mayantú, considerado el dios bondadoso de la selva por las comunidades kukamas y yaguas, y que adopta apariencia zoomorfa para ayudar a los hombres en la caza, pesca y cosecha. ${ }^{18}$ En sus pinturas de paisajes amazónicos, Pablo emplea con frecuencia la técnica del espatulado, como puede apreciarse en su cuadro titulado El renaco. Además, varias de sus obras retratan personajes populares de la vida cotidiana en los pueblos amazónicos. Entre esas obras destaca El cargador de carbón, lienzo de gran formato donado por Pablo Taricuarima al SHRA en noviembre del año 2009.

Hasta aquí, hemos resumido los principales trabajos plásticos y narrativos de los artistas que participaron en los talleres del SHRA. En seguida daremos repuesta a las siguientes interrogantes: ¿Dónde comenzó a gestarse la corriente plástica “indígena amazónica”? ¿Cuál fue el papel del SHRA en la revaloración de la oralidad amazónica? ¿Cómo fue el tránsito de la oralidad a la literacidad de la narrativa indígena amazónica? ¿Cuál es el aporte del SHRA a la producción historiográfica amazónica, el rescate de la oralidad indígena, la etnobotánica y la antropología?

\section{SHRA: Semilla de interculturalidad}

En los últimos años, esta experiencia de trabajo con artistas amazónicos por parte del SHRA ha sido reconocida por otras instituciones. Por ejemplo, el CAAAP en el guión de la muestra Buscando un río. Estéticas y representaciones de los pueblos indígenas amazónicos en Lima (Galería Pancho Fierro, marzo 2014) puso énfasis en la doble función de "laboratorio intercultural y espacio de exhibición” cumplida por el SHRA. En ese sentido, después de transcurridas casi dos décadas desde que comenzó el trabajo precursor con el artista bora Víctor Churay, podemos observar que ese movimiento cultural de reivindicación étnica estuvo inmerso dentro de una preocupación general por los problemas ecológicos y socio-económicos que aquejaron entonces a la Amazonia, como la deforestación, minería ilegal, derrames de petróleo y pobreza extrema. Ese fue el contexto en que los artistas amazónicos forjaron escuelas y tradiciones pictóricas asociadas a sus nombres y los de sus pueblos. Desde ese momento, ellos:

... firman sus obras, exponen en galerías de arte y tienen un estilo personal sin dejar de lado su identidad cultural. Esto es muy importante, porque los museos de arte popular, ya no tendrían artistas amazónicos que figuren como anónimos, podemos incluso seguir sus procesos pictóricos, registro de estilos, los cambios logrados también con la interculturalidad. Fue el Seminario a través de sus curadores quienes realizaron sus primeras exposiciones individuales. ${ }^{19}$

La urbe limeña fue el escenario donde comenzó a gestarse esa corriente “indígena amazónica” (no "indigenista") representativa de las culturas de los pueblos nativos. La pintura indígena con sus cuadros sobre cosmovisiones, espíritus del bosque y escenas históricas o de la vida cotidiana reemplazó al "selvismo pictórico" de la década de 1960, muy criticado por el grupo Bubinzana porque, a diferencia del indigenismo andino, careció de contenido ideológico y declaración de principios. Los selvistas, identificados con el paisajismo, no supieron recuperar las raíces del arte indígena, que no era capturable con los ojos, "sino con el espíritu". ${ }^{20}$ Por ese motivo, los pintores mestizos representantes del selvismo fueron ajenos al "expresionismo mágico" desarrollado por sus pares

18 Soria 2010: 3

19 Arias, T., comunicación personal, 3 de mayo de 2016.

20 Rumrrill 1973: 57. 
nativos, cuyas motivaciones y temáticas rechazaban el materialismo estético occidental que limitaba su imaginación y creatividad. Esa vivencia de lo mágico permitió a los artistas nativos convertir la pintura en el principal vehículo de expresión de su identidad cultural, pues en sus cuadros se manifiesta "la indeleble impronta de la cosmovisión indígena". ${ }^{21}$

A partir del año 2000, las comunidades nativas dieron pasos trascendentales en la defensa de su identidad étnica. En ese sentido, la educación intercultural bilingüe y la ley de consulta previa (Ley N. ${ }^{\circ} 29785$ ) fueron hitos importantes en la definición de una política estatal inclusiva. Por su parte, los círculos académicos promovieron un crecimiento notable del número de exposiciones, congresos, seminarios, ferias, estudios antropológicos, históricos, sociológicos, literarios y lingüísticos sobre los pueblos amazónicos. En el caso concreto de la pintura:

...la presencia de la Amazonía en la escena artística contemporánea peruana y latinoamericana ha sido avasalladora. Galerías, centros culturales y museos han puesto sus ojos en las nuevas expresiones plásticas de artistas autodidactas de diversos pueblos amazónicos, que a través de versátiles y arriesgados discursos visuales en las que predominan arriesgadas propuestas cromáticas que aluden a la particular relación estética que tienen con su entorno. ${ }^{22}$

\section{El SHRA y las lenguas amazónicas}

Desde 1994, Pablo Macera asumió el reto de rescatar y revalorar la oralidad andina y amazónica con el propósito de contribuir a la promoción de la educación bilingüe e intercultural (EBI). Por entonces, la Dirección General de Educación Bilingüe Intercultural (DIGEBIL) del Ministerio de Educación trabajó con curriculos experimentales y planes piloto de formación docente. Ciertamente, los contenidos curriculares no estaban todavía adaptados a las necesidades de los grupos étnicos, pues privilegiaban el castellano y subordinaban a las lenguas nativas. Asimismo, la reducción de días y horas de clase y el carácter unidocente de la mayor parte de escuelas amazónicas dificultaba las labores de aprendizaje. Por esa razón, antes de emprender cualquier proyecto era necesario conocer el estado en que se encontraban las lenguas amazónicas. En mi condición de investigadora del SHRA, una de las tareas que me fue encargada consistió en recopilar bibliografía sobre el proceso de interculturalidad amazónica y establecer comunicación con quienes venían trabajando en el estudio de las lenguas nativas. Fue así como tuvimos oportunidad de editar en 1999 los cuentos amahuaca y culina con apoyo de los lingüistas del Instituto Lingüístico de Verano (ILV).

Por estos años, los docentes de lecto-escritura empleaban materiales didácticos y libros preparados para niños de la costa, que contenían textos e imágenes desconocidos y ajenos a los niños amazónicos, provocando con ello un rechazo a la educación oficial además de generar sentimientos de marginalidad y aislamiento. Los planes de reforma educativa basados en el respeto de la diversidad cultural peruana se remontaban hasta 1972, cuando el gobierno militar, a través de la Política Nacional de Educación Bilingüe (PNEB), reconoció la presencia de numerosas lenguas en nuestro país y expresó su compromiso por preservarlas. Las sucesivas normas legales encaminadas a proteger y preservar las lenguas vernáculas, tales como la Ley General de Educación (Decreto Ley N. ${ }^{\circ}$ 19326) de 1972, la Resolución Ministerial de Educación Bilingüe Nro. 003-73 y la Ley de Comunidades Nativas de 1974 no promovieron una auténtica educación bilingüe intercultural, pues los pueblos indígenas carecían de participación en la elaboración de curriculas y textos. Más

21 Bendayán 2006: 12

22 Yllia 2014: 5. 
aún, las lenguas nativas cumplían un papel secundario en el proceso educativo como lo demuestra el artículo $12^{\circ}$ de la citada Ley General de Educación:

La educación considerará en todas sus acciones la existencia en el país de diversas lenguas que son medio de comunicación y expresión de cultura, y velará por su preservación y desarrollo. La castellanización de toda la población se hará respetando la personalidad cultural de los diversos grupos que conforman la sociedad nacional y utilizando sus lenguas como vehículo de educación. ${ }^{23}$

Con todo, el gobierno de Juan Velasco puso en debate la posibilidad de transitar de una política educacional exclusivamente de "castellanización" a otra bilingüe. Más adelante, las diversas lenguas habladas en nuestro país fueron declaradas patrimonio cultural de la Nación, pero no se les reconoció estatus de lengua oficial, como consta en el artículo $83^{\circ}$ de la Constitución Política de 1979. La Constitución de 1993 en su artículo $48^{\circ}$ sancionó la oficialidad de las llamadas lenguas aborígenes, pero únicamente en "las zonas donde predominen”. Esta disposición constitucional indicó de manera taxativa que:

Todas las personas tienen el derecho a sus identidades étnicas y culturales; que es papel del Estado peruano reconocer y proteger la pluralidad étnica y cultural de la nación, además de promover la Educación Bilingüe e Intercultural según las características de cada zona del país, preservando así las diversas manifestaciones culturales y lingüísticas de sus ciudadanos. ${ }^{24}$

\section{El rescate de la oralidad bilingüe e intercultural}

A fines del decenio de 1990, el SHRA, con grandes esfuerzos y escasos recursos, definió una línea de investigación enfocada en el trabajo directo con los productores (narradores y pintores) de las tradiciones orales andino-amazónicas. Pablo Macera tuvo entonces la idea de recopilar cuentos y publicarlos con textos en columnas paralelas, una en lengua nativa y otra en español. De esa manera, el SHRA contribuiría a la educación bilingüe intercultural con una serie de cuentos para niños acompañados de imágenes. Dos décadas antes, el CAAAP había publicado relatos del pueblo awajún, que estaban dirigidos a los nativos adultos, profesores y antropólogos. El libro Duik Muun: Universo mítico de los aguarunas (1979), reunió cien textos recopilados por Aurelio Chumap Lucía y Manuel García Rendueles, que fueron ilustrados con dibujos y xilografías anexas y transcritos en versión libre adoptando grafías que reproducían aproximadamente los fonemas originales del awajún (Chumap y García 1979, tomo I, p. 31). Asimismo, José Maria Guallart en El mundo mágico de los aguarunas (1989) publicó textos sin ilustraciones sobre mitos, cánticos y poesías de dicho pueblo. Posteriormente, en 1996, los dos tomos titulados Yaunchuk Universo Mítico de los Huambisas, Kanús (Río Santiago) de Manuel García Rendueles reunieron varios mitos de dicho pueblo acompañados de ilustraciones a color realizadas por Gerardo Petsaín Sharúp. Por su parte, los maestros del Programa de Formación de Maestros Bilingües de la Amazonia Peruana-FORMABIAP, debido a su limitado presupuesto, solo publicaron cartillas monolingües, sin incorporar la columna complementaria de lecto escritura en castellano.

En ese sentido, los textos bilingües dirigidos por Pablo Macera destacaron el trabajo de los narradores y dibujantes indígenas reconociéndolos como autores de dichos libros, mientras los

23 Ministerio de Educación 1972: 29

24 Cit. por Huamán 2007: 10. 
historiadores y antropólogos participantes aparecieron como recopiladores. Ese justo reconocimiento que encontraron los artistas nativos en los talleres del SHRA, motivó que ellos asumieran el rescate de sus saberes tradicionales como una forma de realización personal y de compromiso con la cultura de sus pueblos. Los cuentos recopilados y dibujos anexos fueron remunerados a sus autores por Pablo Macera. En el SHRA, a diferencia del CAAAP que recopilaba relatos mediante largas estancias de vivencia en las comunidades, trabajamos con migrantes nativos que visitaban Lima por cortas temporadas. No obstante, en ocasiones realizamos cortas visitas a los lugares de origen de los narradores para complementar la información recibida.

Ciertamente, el objetivo principal de los proyectos ejecutados por el SHRA consistía en brindar espacios y apoyo logístico a los narradores nativos para que pudieran rescatar y difundir sus tradiciones orales. De esa manera, ellos encontraron en el SHRA una tribuna para impulsar la aceptación, reconocimiento y revaloración de sus conocimientos. Con el respaldo de los libros publicados y exposiciones organizadas por el SHRA, varios artistas nativos lograron participar en proyectos culturales de diversas instituciones privadas. Esos fueron los casos de Enrique Casanto (asháninka) y Lastenia Canayo (shipiba). Además, gracias a la labor realizada en los talleres del SHRA, las artistas shipibas Lastenia Canayo (Pecon Quena) y Elena Valera (Bahuan Jisbe) fueron reconocidas como personalidades meritorias de la cultura por el Ministerio de Cultura los años 2014 y 2015 , respectivamente.

En los espacios de interculturalidad creados por el SHRA, los narradores nativos percibieron el valor de la literacidad para transmitir no solo sus cosmovisiones, sino incluso las aspiraciones de sus pueblos que necesitaban utilizar la escritura para "transmitir sus mensajes a un colectivo mayor" y generar debates sobre los problemas que aquejan a la Amazonia, como la actividad contaminante de las empresas petroleras, la creciente deforestación y los conflictos sociales y sobre todo el respeto de las identidades étnicas por parte del Estado. Por ese motivo:

Las recopilaciones colectivas van tomando fuerza y son los maestros bilingües quienes las han propiciado. La especial coyuntura histórica que viven los pueblos indígenas de la Amazonía ha impulsado a los autores a escribir sobre su realidad cotidiana, sus luchas y sobre el saber de sus pueblos con el deseo de trasmitírselos a las nuevas generaciones. ${ }^{25}$

\section{Los primeros relatos publicados por el SHRA}

Los primeros conjuntos de relatos publicados por el SHRA correspondieron a las tradiciones orales amahuaca y culina, pues dichas lenguas se hallaban en peligro de extinción y merecían una atención prioritaria. En ese contexto, dejamos para una segunda etapa la edición de los materiales recopilados en lenguas que poseían mayor cantidad de hablantes (asháninka, shipibo-konibo). Como hemos señalado, Pablo Macera quiso contribuir, desde el SHRA, a la educación bilingüe intercultural proporcionando:

a) Material de lectura que reforzara la identidad de los niños amazónicos.

b) Material gráfico y de lectura para los escolares hispano hablantes de otras regiones. En este caso solo serían utilizadas las columnas en español.

c) Material etnográfico para análisis de los especialistas (antropólogos, lingüistas, etc.).

d) Material de lectura para turistas extranjeros y nacionales interesados en conocer y revalorar la naturaleza y cultura amazónicas (tradición oral, pintura nativa, etc.).

25 Chavarría, 2011. 
La primera serie titulada Llanchama. Cuentos pintados / Amazonia circuló en 1999 y estuvo compuesta por dos textos de tres cuentos cada uno: Amahuaca. Xunivaun Jau Yohipahonni / Cuentos de nuestros antepasados y Culina (Mádija). Bani Tahimari /Cuentos de animales. Ambos libros fueron editados por el Fondo Editorial de la UNMSM con la colaboración del ILV y el INC. Los cuentos culina fueron narrados y pintados por los niños Salomón Montes Ferreira, Lebeo Montes Dsomaji y Magdalena Montes Montes. En el caso de los cuentos amahuaca, Samuel Segundo y Laura Chítomo escribieron los textos y el pintor shipibo Robert Rengifo realizó las ilustraciones. Finalmente, en la revisión y traducción de los textos amahuacas y culinas al español participaron José Piño Bonangué y Margarethe de Chavéz y Cindy Boyer, estas últimas lingüistas del ILV.

En mi condición de coordinadora del área de estudios amazónicos del SHRA, pude constatar que el tránsito de la oralidad a la escritura no resultaba una tarea sencilla debido a la carencia de alfabetos y gramáticas nativos. Al respecto, Pablo Macera nos recordaba que las culturas amazónicas empleaban la tradición oral como principal mecanismo de trasmisión de conocimientos, que estaban sujetos a olvidos y adaptaciones generacionales en el tiempo. La memoria colectiva era un tesoro que debíamos resguardar, pues equivalían a las bibliotecas de las culturas letradas. Existía además un aspecto importante muchas veces subestimado: la memoria de los pueblos nativos se activa mediante representaciones simbólicas: pinturas faciales y corporales, diseños en la cerámica y marcas de caza, entre otras imágenes semióticas. ¿Cuánto de esa tradición visual podía perderse aplicando una política educativa basada exclusivamente en la alfabetización?

Por esa razón, el SHRA puso énfasis en el rescate de la oralidad bajo el principio de que en las culturas nativas es inseparable la presentación simultánea de la imagen y el texto escrito. Definimos entonces un trabajo en dos etapas: primero, coordinamos el tránsito de la tradición oral al registro literario solicitando a los narradores que escribieran sus relatos en formato bilingüe (escritura paralela en lengua nativa e idioma español) con el propósito de fomentar la interculturalidad. En un segundo momento, les pedimos que realizaran dibujos complementarios de los textos, desde su propia perspectiva espacial y estética. Esto último abrió paso a una experiencia singular, pues algunos artistas nativos acostumbrados a la pintura iconográfica (diseños, símbolos) crearon sus propios modelos de pintura figurativa. Sin duda, en esa forma de comunicación subyace el grafismo, que está ligado a las formas de pensar simbólicamente. Quisimos entonces que los textos producidos en el SHRA asociaran pintura y palabra como elementos recíprocamente complementarios e idóneos para expresar las cosmovisiones de los pueblos amazónicos.

De acuerdo a esta misma regla de trabajo preparamos tres libros de cuentos de la tradición oral bora. Esta lengua se encontraba entre las de menor cantidad de hablantes, pues según el censo de 1997 estos no pasaban de 500 individuos. Estos relatos fueron escritos e ilustrados por el artista Víctor Churay Roque, y la revisión de dichos textos estuvo a cargo de Julia Mibeco, conforme al alfabeto y la gramática boras propuestas entonces por los lingüistas del ILV, Wesley y Eva Thiessen. Este alfabeto compuesto por 26 letras o grafías ha sido oficializado mediante Resolución Ministerial n. ${ }^{\circ}$ 512-2015-MINEDU. Sin embargo, debido al escaso número de lectores y usuarios potenciales que ofrece la reducida población bora, las editoriales no mostraron interés en publicar los cuentos preparados en el SHRA, porque estas no realizan tirajes menores de mil ejemplares.

Casi en simultáneo elaboramos cinco textos bilingües shipibo-konibo-español, empleando las narraciones de Herminio Vásquez y los dibujos de Robert Rengifo. Cuatro de estos titulados Nocon Máimea Yoinabo / Los animales de mi tierra, estuvieron dedicados a los mamíferos, aves, peces y reptiles, mientras el último denominado Nocon Máimea Baná Jíhuibo/Las plantas de mi tierra describía las propiedades de diversos árboles selváticos. Estos relatos describían la aparien- 
cia y tamaño del animal, sus hábitos de alimentación y los lugares donde habitaban, así como las preferencias que tenían por la actividad diurna o nocturna, sus épocas de reproducción, las técnicas empleadas para cazarlos y los cuentos o mitos relacionados con el origen de cada especie. A su vez, los relatos sobre plantas diferenciaban las características de los árboles medicinales o maderables precisando sus tiempos de crecimiento, floración y cosecha de frutos, los tipos de terrenos donde era común encontrarlos y su utilidad en la curación de enfermedades o fabricación de herramientas.

En estas narraciones bilingües respetamos los términos coloquiales del español empleados por el narrador Herminio Vásquez, pues nuestro objetivo no solo consistía en que los niños costeños conocieran a los animales descritos, sino que se familiarizaran con el español regional hablado entre los shipibos del Ucayali, a fin de promover la apertura de espacios de diálogo intercultural en las escuelas. Por entonces, la mayoría de materiales escolares de lecto escritura carecía de una perspectiva orientada a la interculturalidad. A pesar de las gestiones hechas para conseguir apoyo editorial estos libros no llegaron a publicarse y solo se imprimieron unos cuantos ejemplares para donarlos a la biblioteca del Instituto Francés de Estudios Andinos (IFEA) y conservarlos en el archivo del SHRA. El profesor Artemio Pacaya revisó los textos para verificar si el narrador había empleado el alfabeto shipibo de 18 grafías y reemplazado la letra " $q$ " por la "k" tal como lo exigía el "Acta de Acuerdo con la Normalización de Lengua Shipibo Conibo" (Huampaní, octubre de 1999) aprobada por la Unidad Nacional de Educación Bilingüe Intercultural (UNEBI) del Ministerio de Educación. No obstante, una Resolución Directoral del año 2007 de la Dirección General de Educación Intercultural, Bilingüe y Rural (DIGEIBIR) oficializó el nuevo alfabeto shipibo de diecinueve grafías y eliminó el uso de la diéresis sobre la grafía sh, a solicitud de la AIDESEP Ucayali.

\section{Colección Cuentos Pintados del Perú}

A mediados del año 2000, Pablo Macera había recopilado cientos de relatos ilustrados andinos y amazónicos, producto de un lustro de intenso trabajo en los talleres interculturales del SHRA. Dos años después, la Fundación Inca Kola publicó parte de ese material dentro de la colección Cuentos Pintados del Perú compuesta por 18 libros, trece de relatos andinos y cinco de relatos amazónicos. Estos últimos contenían los trabajos de los narradores Lastenia Canayo y Herminio Vásquez (shipibos), Enrique Casanto (asháninka) y Romer Yagkug (awajún). Tres de ellos ilustraron sus textos, solo en el caso del libro de Herminio, y por pedido suyo, los dibujos fueron realizados por el pintor shipibo Robert Rengifo. En la revisión de los relatos en lenguas nativas participaron los profesores bilingües Juan Carlos Chávez (shipibo), Anfiloquio Paz Agkuash (awajún) y Pablo Jacinto Santos (asháninka). El vínculo del SHRA con los narradores trascendió el aspecto meramente laboral, pues como ellos no tenían residencia en Lima convirtieron los talleres del Colegio Real en cálidos ambientes amicales, donde podían dedicarse a recordar y pintar, sin condicionamientos ni presiones, los saberes atesorados en su memoria.

Gracias a la Fundación Inca Kola, los dieciocho libros de la colección Cuentos Pintados del Perú se repartieron gratuitamente entre diversas escuelas rurales del país. Estos textos formaron parte del módulo de apoyo al docente llamado La Caja del Saber, que incluyó también un libro sobre la historia de los juegos y juguetes y material lúdico para desarrollar la motricidad gruesa y fina y el razonamiento lógico matemático de los niños. Estas cajas didácticas beneficiaron a 131,420 niños de 4,813 escuelas de 14 regiones (Ica, Moquegua, Tacna, Huánuco, Lambayeque, Tumbes, 
Piura, Apurímac, La Libertad, Cajamarca, Ucayali, Ayacucho, Madre de Dios, San Martín) y diversas zonas de Cusco, Áncash, Amazonas y Lima. ${ }^{26}$

El año 2009 tuvimos oportunidad de coordinar una segunda edición de los Cuentos Pintados del Perú, gracias a la iniciativa del Comité de Damas del Congreso de la República, interesado en fortalecer el desarrollo de las escuelas bilingües interculturales y proporcionar materiales didácticos útiles para formar ciudadanos plenos e integrados con la vida social de su región y del país. Por entonces, el Ministerio de Educación había aprobado los nuevos alfabetos de las lenguas shipiboconibo (Resolución Directoral N. ${ }^{\circ}$ 0337-2007-ED del 13 de setiembre de 20078 y asháninka (Resolución Directoral N. ${ }^{\circ}$ 0606-2008-ED del 4 de noviembre de 2008). En consecuencia, los libros asháninka y shipibo-conibo, editados el año 2002, debían ser revisados y corregidos allí donde fuese necesario. Al respecto, nos reunimos en el SHRA con los profesores bilingües, Aquiles Vásquez (shipibo) y Elfrén Ramos Espíritu (ashaninka) para encargarles dicha tarea. Posteriormente, los textos corregidos por ambos profesores fueron puestos a consideración de las lingüistas María Cortez Mondragón y Elsa Vílchez J. Ellas comprobaron que los cambios de grafías, impuestos por los nuevos alfabetos, no alteraban en absoluto la vigencia semántica de los textos de la primera edición. Ciertamente, la normalización alfabética es un proceso de cambio permanente sujeto a la aprobación de las comunidades hablantes. Además, como advirtió María Cortez, "la oralidad como aspecto inherente a las lenguas indígenas, da lugar a que los hablantes construyan sus propias versiones sobre un mismo tema". ${ }^{27}$

De otro lado, la columna en idioma español respetó los coloquialismos amazónicos utilizados por los narradores, pues constituye un principio básico de la interculturalidad reconocer esas formas legítimas de comunicación, aun cuando algunos lingüistas y literatos son partidarios de proscribirlos del habla cotidiana. Al respecto, Alberto Escobar desvirtuó esa opinión, aduciendo que con frecuencia y erradamente "los conservadores asociaban mecánicamente habla culta con educación y habla coloquial con ignorancia”. ${ }^{28}$ Existen además fronteras semánticas entre las palabras del español y las lenguas nativas que empleamos para referirnos a similares hechos o conceptos. Por ejemplo, lo que en español se entiende por cuento, en el sentido de relato mágico, para los nativos significa el lenguaje metafórico con que describen sus relaciones con los espíritus de las plantas, animales, cascadas, bosques, ríos, cochas, etc.). En ese sentido, el filósofo awajún, Edinson Tsajuput, en su comentario sobre los cuentos editados por el Congreso, señaló que los seres:

... atribuidos como "mágicos" son tan reales como la misma realidad. Ahora el "lenguaje metafórico" en este caso se cumple cuando los seres reales también son reales cuando se ven "mediante la toma de algunas plantas", pero lo son a un nivel "molecular (y tridimensional)”. ${ }^{29}$

\section{El tránsito de la oralidad a la literacidad en el SHRA}

De acuerdo con la lingüista María Chavarría, la literacidad constituye el conjunto de prácticas sociales surgidas en torno a la escritura. En el caso de los pueblos nativos, la oralidad y los sistemas simbólicos enmarcan y condicionan esa literacidad. En el proyecto Pintura y Palabra, desarrollado en los talleres del SHRA, se manifestaron varias formas del tránsito de la oralidad a la literacidad. 
Algunos narradores deseaban escribir e ilustrar ellos mismos sus relatos. En este caso, el dibujo era una extensión de la palabra que materializaba sus vivencias. Sin embargo, otros preferían contarnos sus historias mediante dibujos antes que escribirlas, como sucedió con Roldán Pinedo y Elena Valera. También hubo quienes escribían y dejaban que otros pintores nativos ilustraran sus relatos. Esto sucedió con los shipibos Herminio Vásquez (narrador) y Robert Rengifo (pintor). Algo similar, pero en sentido inverso, se produjo durante la edición del libro Demonios Asháninkas y respuestas humanas, por parte de Javier Macera y María Heise, a partir de la asociación de los dibujos del pintor asháninka Moisés Torres con los relatos de Enrique Casanto, narrador asháninka del SHRA.

El escaso dominio del castellano y el desconocimiento del medio escrito, empujaron a Moíses a pintarnos su mundo, tal cual lo percibe y entiende. Si bien este esfuerzo plástico permitía visualizar el mundo según los asháninkas, constituían imágenes de una cosmovisión que requería de mayor precisión y contenido. Ante la imposibilidad de reunirnos con Moisés, una alternativa era que algún miembro de la cultura asháninka interactuase con su pintura. El encuentro con Enrique Casanto hizo posible esta vía. Al mirar las pinturas, Enrique reconoció episodios míticos de su pueblo. (...) Así respetamos su propia frontera etno lingüística. ${ }^{30}$

Estos narradores descubrieron además la necesidad de expresar sus historias personales (testimonios, autobiografías) y las de sus pueblos (tradiciones orales). Entre los primeros, podemos mencionar los textos Testimonio y cuentos shipibos (1999) de Laurencio Ramírez Cairuna, que recopila diversos relatos de Guillermo Ramírez y los de su padre, Apolinario Ramírez, sobre la colonización del Ucayali, y Encantos y desencantos: la oralidad mixta de los relatos de Félix Chumacero Agurto (2010), que recoge sus vivencias en la sierra piurana y sus encuentros con seres mágicos en los caminos que van de Huancabamba hacia Cajamarca. Los relatos de don Félix pertenecen a la llamada "oralidad mixta", aquella que se expresa combinando elementos de la escritura con toda clase de enunciados metafóricos. Él además ilustró sus textos con expresivas composiciones figurativas donde formas y colores se fusionan armónica y espontáneamente, alejándose de cualquier convencionalismo académico. Por su parte, Laureano Ríos Cairuna, preocupado por el desconocimiento del significado de los kené entre los jóvenes shipibos, recorrió varias comunidades de la cuenca del Ucayali, consultó a los ancianos y elaboró un registro publicado con el título de 145 Diseños shipibo-conibo (2003). La prosa sencilla de estos narradores permite a los lectores urbanos:

... presenciar un sensible canto de sabiduría, un tributo permanente a la cotidianidad donde se gesta el universo, un lenguaje que encontró la tierra para no dejarse morir y hacerse palabra y por cada vez que se escriba y se pronuncie, ella asegurará sus latidos. ${ }^{31}$

\section{La Historia y la “otra historia” amazónica}

La compilación de fuentes primarias y material hemerográfico, útiles para reconstruir la historia amazónica, fue otro de los proyectos emprendido por el SHRA en la década de 1990. Además de la catalogación del fondo Tierras de Montaña del Archivo General de la Nación y la selección documental realizada en el Archivo Arzobispal de Lima, durante tres años (1995-1998), bajo la

30 Heise y Macera 2000: 5.

31 Sepúlveda 2014: 139. 
dirección de Pablo Macera, revisamos los diarios El Peruano y El Comercio, desde su fundación hasta las primeras décadas del siglo XX, para fichar todos los artículos referidos a cuestiones amazónicas. En los citados diarios, conservados por el Banco Central de Reserva y el Instituto Riva Agüero, encontramos memorias de autoridades, proyectos de colonización, diarios de navegación, noticias enviadas por corresponsales y ensayos escritos por literatos y exploradores que recorrieron los principales ríos amazónicos (Marañón, Ucayali, Madre de Dios, etc.) y sus tributarios. Con esa información elaboré tres trabajos que analizaron las políticas de colonización y administración del espacio amazónico por parte del Estado peruano entre 1821 y 1921.

El Dorado Republicano. Visión oficial de la Amazonia peruana 1821-1879, publicado el año 2006, detalla cómo en dicho período las élites introducen en el imaginario nacional la visión de una Amazonia plena de tesoros por explotar. En ese contexto, examinamos el ejercicio gubernativo en oriente, a partir del papel cumplido por las instituciones encargadas de administrar esta región. Al año siguiente, Colonización amazónica 1884-1900 estudió la ocupación de la montaña por el Estado peruano durante la posguerra del Pacífico, expuso las causas de la decadencia misionera oriental y precisó las nuevas exploraciones y rutas que redefinieron las fronteras selváticas y la organización administrativa encargada de elegir las zonas favorables para la colonización. Finalmente, Viajeros al Infierno Verde. Madre de Dios, 1893-1921, editado el año 2008, rastrea el impulso colonizador generado por la fiebre del caucho y las disputas surgidas entre patrones bolivianos, brasileños, españoles, ingleses y peruanos por controlar y explotar los manchales repartidos por la cuenca del Madre de Dios y sus afluentes.

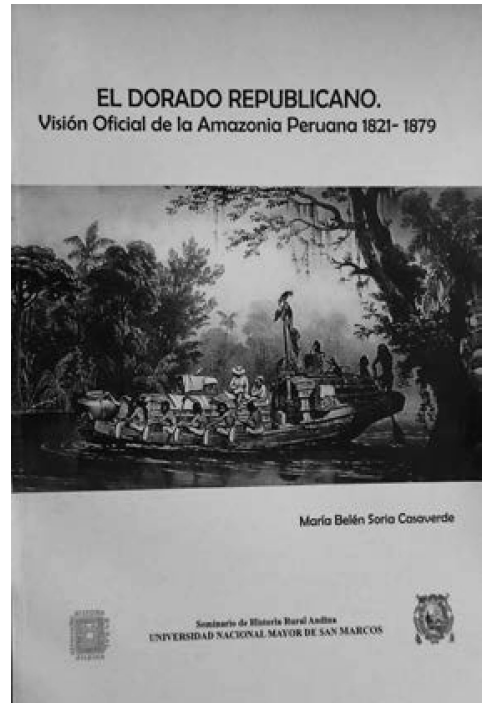

Carátula del libro El Dorado Republicano Visión Oficial de la Amazonía Peruana 1821-1879, Lima-2006.

En cuanto a la publicación de fuentes sobre la historia amazónica destacan los trabajos Viajes a las montañas de Maynas, Chachapoyas y Pará. Vía de Amazonas (2007) de Nanda Leonardini y Colonia del Perené: Presencia inglesa en la Amazonía peruana (2010) de Santiago Tácunan. En el primer caso, Leonardini reunió en un volumen los capítulos de los Viajes de Ijurra aparecidos en El Peruano entre setiembre de 1849 y febrero de 1850. Dicho texto sintetiza la imagen decimonónica de la Amazonia, considerada entonces una reserva de materias primas exportables. Ijurra propuso hacerlo por la vía del Atlántico y mencionó en apoyo de su idea el viaje realizado por José Valdez y Palacios entre Cusco y el Pará (1846). Por otro lado, Santiago Tácunan publicó Colonia del Perené: Presencia inglesa en la Amazonía peruana (2010) con documentos e informes financieros inéditos sobre los primeros cincuenta años de la actividad colonizadora de la Peruvian Corporation en la selva central.

El SHRA contribuyó además al conocimiento de la historia gráfica de la Amazonia mediante la exhibición de tres álbumes inéditos del cauchero Julio César Arana, que contenían fotografías realizadas por Silvino Santos, Manuel Rodríguez Lira, Victoriano Gil y el explorador alemán Hans Heinrich Brüning. Este material, descubierto por Pablo Macera en la década de 1980, ofrecía vistas sobre las diversas secciones caucheras del Putumayo, los espacios urbanos (calles, cuartel y escuelas) de Loreto, caminos orientales (Rioja hacia la costa peruana), accidentes geográficos (Pongo de Manseriche) y embarcaderos (pueblo de Motupe). Había además un grupo especial de fotografías y fototipias de la familia Arana-Zumaeta, donde se podía apreciar el mundo privado del 
denostado cauchero. Este material se exhibió por primera vez en la Sala de Exposiciones del Colegio Real entre noviembre-diciembre del 2014, bajo el título Julio C. Arana. Álbumes fotográficos inéditos. Colección Pablo Macera.

Durante el desarrollo de los talleres interculturales, surgió entre los narradores el deseo de escribir las ideas que ellos tenían de los héroes y personajes históricos que les habían enseñado en la escuela. Además, ellos quisieron rescatar de la memoria histórica de sus pueblos los hechos más significativos en la constitución de su identidad. De esa manera, Enrique Casanto (asháninka), Gladis Mascco (quechua de Ayacucho), Robert Rengifo (shipibo-konibo) y Romer Yagkug (awajún) nos presentaron relatos y dibujos sobre su visión de la historia peruana, es decir, la "otra historia”, aquella construida desde la perspectiva de los pueblos nativos. El historiador Alejandro Salinas coordinó este trabajo orientado a buscar los puntos de encuentro y divergencia entre la historia oficial y la memoria histórica indígena. Los textos producidos por los cuatro narradores (Casanto, Mascco, Rengifo y Yagkug) reflejaron sus diferentes niveles de formación social y aprendizaje educativo, y fueron editados el año 2004 dando origen a un libro y una exposición de similar título: La otra historia: héroes populares del Perú.

En esta área de la historia oral, Enrique Casanto nos sorprendió con sus relatos y dibujos sobre el invencible movimiento de Juan Santos Atahualpa, principal epopeya de resistencia indígena surgida en la Amazonia central durante el siglo XVIII. La exposición Cosmovisión Asháninka. Enrique Casanto, realizada por el SHRA en la Sala de Exposiciones del Colegio Real en mayo del año 2003, reveló parte de ese valioso material gráfico. Años después, el Fondo Editorial de la Universidad San Martín de Porres editó el libro titulado El Poder Libre Asháninca. Juan Santos Atahualpa y su hijo Josecito (2009), que contenía relatos acerca del origen de la gran rebelión e informan sobre la existencia del líder asháninka "Niño Josecito", hijo de Juan Santos Atahualpa y continuador de la obra liberadora de su padre.

Los relatos ilustrados de Casanto dan cuenta de cómo los asháninkas han elaborado el recuerdo histórico de la gesta de Juan Santos Atahualpa, muy distinto por cierto a la historia registrada por los franciscanos en sus crónicas coloniales. Para el pueblo asháninka, Juan Santos Atahualpa simbolizó la síntesis entre Andes y Amazonia, pues este fue hijo del curaca y guerrero asháninka José Santos Shingari y María Atahualpa Coya, descendiente del Inca Atahualpa y "nieta del Padre Sol". En las narraciones de Casanto, Juan Santos Atahualpa asume el rol de Inca y héroe pan-indígena, cuya misión histórica es liberar a su gente de la opresión española. Expulsados los españoles de la selva central y muerto Juan Santos Atahualpa surgió la necesidad de afirmar la unión interétnica. Esta tarea fue asumida por su hijo y sucesor, José Santos Márquez, llamado "niño Josecito". Como auténtico "Dios de la Paz", Josecito recorrió, ayudado por los guerreros Patyari y Shencari, los valles de la Convención, Urubamba, Tambo, Perené, Gran Pajonal, Ene, etc. llevando hasta allí su mensaje de concordia.

Ante la vitalidad de la memoria asháninka rescatada por Enrique Casanto, nos preguntamos en el SHRA ¿hasta qué punto esos recuerdos colectivos eran historia? Al respecto, Pablo Macera consideró de suma importancia la distinción entre memoria e historia planteada por Marta Zambrano y Cristóbal Gnecco, según los cuales la memoria es aquello que los grupos colectivos recuerdan mientras que la historia dice lo que deben recordar. De esa manera, la historia resulta como una domesticación política de la memoria social por parte de los grupos hegemónicos. Por ese motivo, Pablo Macera consideró indispensable que la memoria asháninca debía seguir siendo tal, a fin de 
que sea libre y adquiera poder ${ }^{32}$ Sin duda, el caso de Enrique Casanto era notable, porque "la profundidad de su memoria llega casi a los trescientos años y resulta comparable con cualquiera de los ejemplos que a mediados del siglo XX recogió [Jan] Vansina en Africa”. ${ }^{33}$

\section{Etnobotánica y antropología amazónicas}

El primer trabajo del SHRA dedicado al estudio de los pueblos amazónicos fue escrito en 1982 por Carlos Dávila bajo el título de Etnohistoria y artesanía shipiba. Después de un silencio de varios años, esta línea de investigación se reactivó a partir de 1997 con la llegada de los narradores nativos a los talleres interculturales del SHRA. Sin embargo, solo Enrique Casanto pudo participar en los proyectos de estudios etnobotánicos y antropológicos iniciados el año 2000, gracias a que fue contratado por la UNMSM. Al año siguiente, Casanto publicó dos libros en coordinación con Javier Macera y Belén Soria: Variedades de la yuca entre los ashánincas y Cuentos Ashánincas del Perené, respectivamente. El primero abordó el origen mítico de las 32 variedades de yuca cultivadas por los asháninkas y las relaciones de esta planta con divinidades y otros seres mágicos de la Amazonia. El segundo presenta un conjunto de relatos de la tradición oral de los pueblos asháninkas de las cuencas del Perené, Pichis y otras de la selva central. Dichos textos hablan

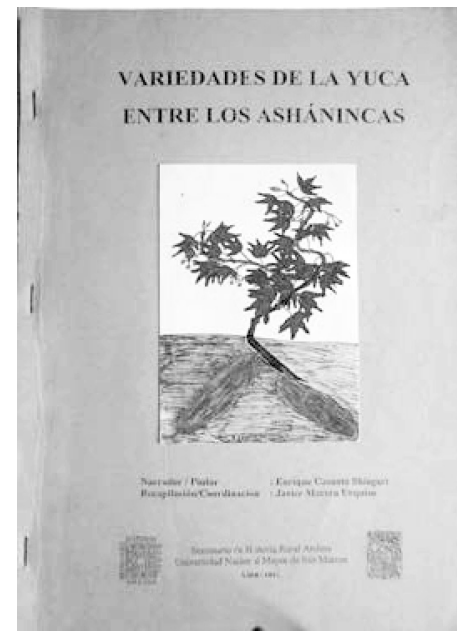

Carátula del libro Variedades de la Yuca entre los Ashánincas. Lima-2001. de aquellos tiempos legendarios en que los animales fueron personas, y nos cuentan cómo estos perdieron su apariencia humana por haber trasgredido las normas consuetudinarias de la vida comunal o en su afán de obtener poderes o virtudes mágicas.

En el libro Arte y Cultura del Monte Asháninca del Perené (2002), analizo desde una perspectiva cultural el proceso de fabricación de herramientas por parte del citado pueblo. Sin duda, los soportes materiales utilizados y los criterios estéticos con que se decoran los utensilios domésticos o laborales responden a concepciones mágico-religiosas, por las cuales el objeto se convierte en una forma artística de humanización de la naturaleza. Actualmente, esta tradición artesanal corre el riesgo de perderse, porque el ingreso de artículos de plástico, resistentes y fáciles de conseguir, están desplazando la fabricación de varios utensilios como las matzitas (platos hechos con calabazas). Por ese motivo, Casanto registró y dibujo las materias primas (maderas y plantas) empleadas en su fabricación, las técnicas de trabajo artesanal, el uso dado a los objetos según género y los elementos religiosos (dioses o personajes mitológicos) vinculados a su origen.

Posteriormente, Casanto emprendió sus propias investigaciones centradas en el estudio de la cosmovisión, tradición oral y cultura material asháninkas. Su primer libro titulado Sankenarentsi opoñaanaka kinkitsarentsi. Escritura y cuentos (2003), es una cartilla alfabética ilustrada de la lengua asháninka, que contiene además cuentos dirigidos a los niños. El año 2005 publicó Piri Piri. Plantas medicinales, texto dedicado a las veinte variedades del ibenki o piri piri (Cyperus articulatus) y sus propiedades medicinales, que son conocidas por los curanderos asháninkas. Asimismo, su texto Naturaleza amenazada (2006) describe las especies de flora y fauna amazónicas en peligro de extinción y denuncia el uso indiscriminado de estos recursos naturales por parte de los migrantes 
mestizos. En los años siguientes, editó cuatro libros titulados La pituca y otras plantas medicinales de la Amazonia (2007), Plantas medicinales para pescar en la selva amazónica (2008), Plantas para cazar de la Amazonía peruana (2009) y Frutos comestibles de nuestra Amazonía (2010). En todos estos encontramos saberes etnobotánicos producidos por el pueblo asháninka. Finalmente, Casanto editó sus libros Contemos en asháninca (2011) y Canciones ashánincas (2013), donde nos explica la particular forma de contar de su pueblo y las canciones que animan sus fiestas y rituales.

En cuanto a mis investigaciones, puse énfasis en el estudio de la comunicación semiótica en los pueblos nativos. Al respecto, publiqué dos trabajos: Introducción al mundo semiótico de los diseños shipibo-conibo (2004) y El discurso de las imágenes: Simbolismo y nemotecnia en las culturas amazónicas (2009). El primero se propuso reconstruir el contexto histórico en que surgió el patrón semiótico (kené) de comunicación visual entre los shipibo-conibo. En ese sentido, definimos los elementos iconográficos propios y aquellos surgidos a partir de la influencia Inca. Además, ofrecí un primer registro de kenés hechos por tres artistas shipibas. Este texto fue citado por el antropólogo francés Pierre Déléage en su artículo "Les répertoires graphiques amazoniens", aparecido en el número 93 de la Journal de la Societé des Américanistes del año 2007. Aunque este trabajo dejó aspectos pendientes por investigar, obtuvo el reconocimiento de Luisa Elvira Belaúnde, que lo consideró "pionero en el área" ${ }^{34}$ En abril del 2008, la doctora Belaúnde y el colectivo de artistas shipibo-konibo Barin Babado consiguieron que el kené fuese declarado patrimonio cultural de la Nación. En el segundo trabajo citado, analizamos la forma cómo las culturas amazónicas conjugaron simbolismo y nemotecnia para construir sistemas de comunicación visual basados en unidades semióticas.

De otro lado, el texto Demonios del Monte. Idea del mal en la cosmovisión amazónica (2005) estudió la noción de lo maligno y sus representaciones mágico-espirituales en las culturas amazónicas, precisando las influencias ideológicas introducidas por los misioneros católicos. Por su parte, Rommel Plasencia Soto y Melisa Sánchez Vásquez publicaron Recursos turísticos en las comunidades ashánincas de la selva central peruana (2012), donde ofrecen un minucioso inventario de bosques, montañas y petroglifos repartidos por los territorios de las comunidades asháninkas de la provincia de Chanchamayo (Junín) y las rutas que deben seguirse para llegar hasta estos. Los autores, desde la perspectiva de la antropología del turismo, advirtieron también sobre el poder transculturizador de la actividad turística sobre los pueblos indígenas.

En este segundo período, el SHRA produjo 64 textos entre libros, catálogos y dípticos de exposiciones, suma que repartida entre los dieciséis años transcurridos entre 1997 y 2015 arroja un promedio de cuatro publicaciones por año. De esa manera, el SHRA proveyó a la comunidad académica de información y reflexiones novedosas sobre oralidad y arte nativos. Muchos de esos materiales han sido utilizados como punto de partida para la elaboración de proyectos de tesis (Yllia, 2011 y Castillo, 2013). Además, varios de estos trabajos del SHRA han sido registrados por la Internacional Bibliography of Historical Sciencies (2006) y la revista Journal de la Société des américanistes (2007). En el caso de los narradores y pintores nativos participantes de los talleres interculturales del SHRA, estos han sido promotores de nuevas expresiones de narrativa y arte amazónicos, que han generado nuevos enfoques antropológicos e históricos sobre las culturas indígenas.

En ese sentido, la antropóloga Luisa Elvira Belaunde señala:

34 Belaunde, L.E., comunicación por correo, 15 noviembre de 2012. 
La nueva pintura amazónica que germinó en los talleres de Arte Popular [del SHRA] se caracteriza por ser una pintura testimonial, cuya fuerza proviene de las experiencias vividas por las y los artistas y por los parientes que los criaron. Detrás de la riqueza de formas y estilos, colores, materiales y texturas, está el trabajo minucioso de personas con vidas duras y esforzadas que lograron producir nuevas imágenes para traducir visualmente sus vivencias del pasado y de lo cotidiano, de lo que aprendieron con sus ancestros, lo que soñaron y las visiones inmateriales por medio de las cuales las plantas y otros seres del cosmos les otorgaron poderes. Sus cuadros no revelan quimeras. No muestran seres artificialmente compuestos ni inventados, sino seres que nos quieren enseñar a ver de otra manera. De este modo, nos familiarizan con la transformabilidad de las imágenes de la selva que no obedecen a la obligación de tener una forma fija. En sus pinturas, cada artista demuestra la singularidad de su recorrido por las comunidades, los ríos, los bosques y las ciudades. Su efecto provoca una transformación de nuestra mirada. ${ }^{35}$

Asimismo, Maria Inês de Almeida, profesora de la Universidad Federal de Minas Gerais (Brasil) destaca el papel del SHRA como institución constructora de ideas, que abre caminos a los demás, escucha las otras historias y establece diálogos interculturales.

Um seminário, como um canteiro de ideias, um lugar onde brotam relações. Uma experiência real, no sentido em que abre caminhos a outros - a técnica do próprio caminho. Para mim, o Seminário de História Rural Andina, liderado pelo professor Pablo Macera, mostra que nossas universidades latino-americanas têm um caminho próprio, e ele passa pela arte, pela literatura, pela história, próprias. Talvez seja uma busca difícil, esta do diálogo entre civilizações. Há que se ouvir a história do outro. Visitando duas vezes o SHRA, inclusive quando conheci o artista Enrique Casanto, vi ali uma real tentativa de produção de conhecimento com o indígena, em carne e osso, com uma troca verdadeira de pensamentos, de sentimentos. Um caminho que me ensinou muito. ${ }^{36}$

\section{(Traducción al español)}

Un seminario, como una cantera de ideas, un lugar donde nacen relaciones. Una experiencia real, en el sentido en que abre caminos a otros - la técnica del propio camino. Para mí, el Seminario de Historia Rural Andina, liderado por el profesor Pablo Macera, muestra que nuestras universidades de América Latina tienen su propio camino, y este pasa por el arte, la literatura y la historia propia. Tal vez sea una búsqueda difícil, esto del diálogo entre civilizaciones. Donde hay que oír la historia del otro. Visitando dos veces el SHRA, inclusive cuando conocí el artista Enrique Casanto, vi allí una real tentativa de producción de conocimiento con el indígena, en carne y hueso, con un cambio verdadero de pensamientos, de sentimientos. Un lugar que me enseñó mucho.

\section{Reflexiones finales}

Las páginas precedentes exponen de manera detallada cómo se forjaron en el SHRA dos grandes líneas de investigación en Amazonía: una dedicada a estudios históricos y antropológicos, y otra que abordó temas de arte y narrativa interculturales. En ambos casos, la producción bibliográfica del SHRA ha logrado el reconocimiento de la comunidad académica nacional e internacional. A

35 Belaunde, L. E., comunicación personal, 2 de mayo de 2016.

36 Almeida, M. I., comunicación personal, 5 de abril de 2016. 
manera de conclusión, resumimos en siete puntos las contribuciones del SHRA al desarrollo del conocimiento de la Amazonia:

1) En una primera etapa (1977-1997), el SHRA ubicó, seleccionó y reprodujo nuevas fuentes primarias y hemerográficas que contenían informes de autoridades civiles y eclesiásticas, relatos de viajeros y ensayos indispensables para renovar la historiografía amazónica peruana.

2) A partir de una segunda etapa (1997-2016), el SHRA abre talleres interculturales donde recibe a diversos pintores nativos, que forjan propuestas artísticas identificadas con las cosmovisiones de sus pueblos, como sucedió con la escuela de la Llanchama representada por Víctor Churay.

3) Facilitó espacios a los narradores nativos para que estos mediante relatos cortos, cuentos, mitos, leyendas y testimonios nos entregaran la versión escrita de la "otra historia”, alternativa a la historia oficial de la Amazonia.

4) Reveló a la comunidad académica un conjunto de nuevos saberes sobre etnobotánica, lingüística y cosmovisiones nativas.

5) Destacó la importancia del trabajo de los narradores-pintores nativos, quienes tuvieron libertad para elegir los temas que deseaban escribir e ilustrar.

6) Respetó el derecho de los narradores-pintores a consignar su autoría en los libros publicados, indicándose al mismo tiempo que los investigadores cumplían el papel de recopiladores y/o presentadores.

7) Creó espacios para el desarrollo de la literacidad indígena amazónica en el contexto urbano capitalino.

\section{Bibliografía}

Bendayán, Christian (2009). "El arte amazónico y el realismo mágico”. Bajo la lupa, 2, (12), pp. 12-13.

Burga, Manuel (30 de abril de 2009). “La memoria como poder”. La República. Recuperado en: http://blog.pucp.edu.pe/blog/ridei/2009/04/30/la-memoria-como-poder/

Centro Amazónico de Antropología y Aplicación Práctica (CAAAP) (2014). Buscando un río. Estéticas y representaciones de los pueblos indígenas amazónicos en Lima. Texto del guión museográfico de la exposición realizada por la Galería Municipal de Arte Pancho Fierro.

Camino, Alejandro. (1979). "Trueque correrías e intercambios entre los quechuas andinos y los piro y machiguenga de la montaña peruana”. Amazonia Peruana, I, (2), pp. 123-140

Casa de la Literatura (2016). Conversatorio "Las artes plásticas: narrativas y memorias". Lima, Casa de la Literatura. Recuperado en: http://www.bing.com/videos/search?q=Las+artes+p $1 \%$ c3\%alsticas\%3a+narrativas $+\mathrm{y}+$ memorias\&FORM=HDRSC3

Castillo, Daniel (2013). "Pintando en Shipibo": el arte de Cantagallo en Lima desde un contexto sociocultural. Los casos de Elena Valera, Roldán Pinedo y, los hermanos Guímer y Rusber García. Lima: Pontificia Universidad Católica del Perú. Tesis de maestría.

Chavarría, María (2011). "De la oralidad a la literacidad: aproximaciones recientes en la Amazonía”. Jean-Pierre-Chaumeil, Óscar Espinoza y Manuel Chaparro (eds). Por donde hay soplo. Lima: IFEA-PUCP-CAAAP.

Churay, Víctor y María Belén Soria (2001). Fiestas tradicionales de los bora. Lima: Seminario de Historia Rural Andina, Universidad Nacional Mayor de San Marcos. 
Déléage, Pierre (2007). "Les répertoires graphiques amazoniens", Journal de la Société des Américanistes, 93, ( 1), pp. 97-126.

Escribano, Pedro (18 de octubre de 1998). “El Guamán Poma amazónico”. La República, p. 36.

Heise, María y Javier Macera (2000). Demonios Asháninkas y respuestas humanas. Lima: Noceda Editores.

Huamán Cosi, Melchor (2007). Educación Bilíngüe Intercultural (EBI) en el Perú, Siglo XXI. Texas, Universidad de Texas. Disponible: http://lanic.utexas.edu/project/etext/lilas/ilassa/2008/cosi.pdf

Macera, Javier y María Belén Soria (2003). Cosmovisión asháninca. Enrique Casanto. (catálogo). Lima: Seminario de Historia Rural Andina, Universidad Nacional Mayor de San Marcos.

Macera, Javier y María Belén Soria (2007). Como un avispero. Cosmovisión nomatsiguenga. Domingo Casancho. (Catálogo). Lima: Seminario de Historia Rural Andina, Universidad Nacional Mayor de San Marcos.

Macera, Pablo (1992). Geografía Amazónica. 3 volúmenes. Lima: Seminario de Historia Rural Andina, Universidad Nacional Mayor de San Marcos.

Macera, Pablo (2004). "Presentación”. Texto del tríptico de la exposición Lágrimas del piri-piri. Pinturas y esculturas de la selva. Lima: Biblioteca Nacional del Perú.

Macera, Pablo (2009). Trincheras y fronteras del arte popular peruano: ensayos. Lima: Fondo Editorial del Congreso de la República.

Macera, Pablo (2009). El poder libre Asháninka. Juan Santos Atahualpa y su hijo Josecito. Lima: Fondo Editorial, Universidad San Martin de Porres.

Mastrogregori, Massimo (editor). (2006). International Bibliography of Historical Sciences, volumen 75. Berlín. Recuperado de: https://www.degruyter.com/view/product/43472

Miasta, Jaime (1979a). El Alto Amazonas. Arqueología de Jaén y San Ignacio. Perú. Lima: Seminario de Historia Rural Andina, Universidad Nacional Mayor de San Marcos.

Miasta, Jaime (1979b). El Alto Amazonas. Arqueología de Jaén y San Ignacio. Perú. Anexo. Lima: Seminario de Historia Rural Andina, Universidad Nacional Mayor de San Marcos.

Ministerio de Educación (1972). Política Nacional de Educación Bilingüe. Lima: Dirección Central de Publicaciones.

Morales, Daniel (1979). Hacia las rutas de Vilcabamba: último reducto de resistencia incaica. Lima: Seminario de Historia Rural Andina, Universidad Nacional Mayor de San Marcos.

Morales, Daniel (1981). Los alfareros de Huánuco. Lima: Seminario de Historia Rural Andina, Universidad Nacional Mayor de San Marcos.

Muñoz, David. (1980). La Memoria sobre la amazonia peruana. Lima: Seminario de Historia Rural Andina, Universidad Nacional Mayor de San Marcos.

Peralta, Luz (1993). Catálogo de la Sección Tierras de Montaña: 1887-1964. Lima: Seminario de Historia Rural Andina, Universidad Nacional Mayor de San Marcos.

Rumrrill, Roger (1973). Reportaje a la Amazonia. Lima: Ediciones Populares Selva.

Rumrrill, Roger (2008). La Amazonía peruana: la última renta estratégica del Perú en el s. XXI o la tierra prometida. Lima: Programa de las Naciones Unidas para el Desarrollo (PNUD).

San Román, Jesús (1994). Perfil histórico de la Amazonia peruana. Iquitos: CETA-CAAAP-IIAP.

Sepúlveda, Betsimar (2014). "Percepción de la imagen en la poética indígena”. Mundo Amazónico, 5, pp. 135-140.

Soria, María Belén (1998). Llanchamas bora. Víctor Churay. Lima: Banco Central de Reserva del Perú. 
Soria, María Belén (2001). Arte Shipibo. Roldán Pinedo y Elena Valera (pintores). Lima: Seminario de Historia Rural Andina, Universidad Nacional Mayor de San Marcos.

Soria, María Belén y Enrique Casanto (2002). Arte y cultura del monte. Lima: Seminario de Historia Rural Andina, Universidad Nacional Mayor de San Marcos.

Tsajuput, Edinson (16 de abril de 2010). Comentario de la colección Cuentos Pintados del Perú (Asháninka, Shipibo-konibo y Awajún). [Mensaje en blog] AYAMTAI, Recuperado de: http://eayamtai.blogspot.pe/2010/04/comentario-de-la-coleccion-cuentos.html

Tinajero, Fernando (1995). "Cultura popular y cultura académica: un problema mal planteado". I Seminario de Historia del Arte: "Artes académicas y populares del Ecuador". Quito: Fundación Paul Rivet y Abya-Yala.

Úrsula, Elsa (coord.) (2005). La educación rural en el Perú. Lima: Fundación Inca Kola - Instituto Apoyo.

Valdivia, Fernando (2003). Buscando el Azul. Lima: TeleAndes Producciones.

Wilkens de Mattos, João (1991). Diccionario topográphico do departamento de Loreto na República do Perú. Lima: Seminario de Historia Rural Andina, Universidad Nacional Mayor de San Marcos.

Yllia, María Eugenia (2009). "De la maloca a la galería: La pintura sobre llanchama de los boras y huitotos de la Amazonía Peruana”. Illapa, 6, (6), pp. 95-107.

Yllia, María Eugenia (2011). Transformación e identidad en la estética amazónica, la pintura sobre llanchama del artista bora Víctor Churay Roque. Lima: Universidad Nacional Mayor de San Marcos. Tesis de licenciatura.

Yllia, María Eugenia (2014). “Introducción. Arte amazónico peruano contemporáneo”. En: Pintura Amazónica Contemporánea del Perú. Proyecto de exposición presentado por Jean Marc Desrosiers y Nancy Ochoa. París, pp. 5-6.

Fecha de recepción: 29/VIII/2016

Fecha de aceptación: 30/IX/2016 